\title{
Geometry of Middle to Late Triassic extensional deformation pattern in the Cordillera del Viento (Southern Central Andes): A combined field and geophysical study
}

\author{
L. Sagripanti ${ }^{1 *}$, A. Folguera ${ }^{1}$, M. Giménez ${ }^{2}$, E. A. Rojas Vera ${ }^{1}$, J. J. Fabiano ${ }^{1}$, N. Molnar ${ }^{1}$, L. \\ Fennell ${ }^{1}$, V. A. Ramos ${ }^{1}$ \\ 'Laboratorio de Tectónica Andina. Instituto de Estudios Andinos "Don Pablo Groeber" (IDEAN). Universidad de \\ Buenos Aires - CONICET. Buenos Aires, Argentina \\ ${ }^{2}$ Instituto Geofísico-Sismológico "Ing. F.S. Volponi" (IGSV). Facultad de Ciencias Exactas, Físicas y Naturales \\ Universidad Nacional de San Juan, Argentina
}

e-mail addresses: lusagripanti@gmail.com (L.S., *correspondingauthor) andresfolguera2@yahoo.com.ar (A.F.); gimmario@gmail.com (M.G.); erv081@yahoo.
com.ar(E.A.R.V.); jif899@@hotmail.com (J.J.F.); nicolas.molnar@hotmail.com (N.M.); lucasfennell90@gmail.com (L.F.); andes@gl.fcen.uba.ar (V.A.R.)

Received: 1 August 2013 / Accepted: 5 May 2014 / Available online: 25 June 2014

\begin{abstract}
Combined field and gravimetric-magnetic data reveal a complex pattern of extensional structures superimposed to the late Carboniferous - Early Permian Gondwanan orogen at the inner sectors of the Southern Central Andes, in the westernmost part of the Chos Malal fold and thrust belt at the cordillera del Viento area. W-NW, NW basement structures of regional significance, segmented by minor NE structures are bounding Late Triassic depocenters and structural highs corresponding to the cordillera del Viento rifting, equivalent to the Precuyo cycle. A pattern of roughly N-S trending structures recognized in the field associated with Andean thrusts do not show evidences of previous structural controls, as they cut the magnetic anomalies. Field observations show that W-NW, NW and NE normal structures control changes in Late Triassic sedimentary thicknesses and are associated with synextensional geometries. Our model indicates that Late Triassic rifting in the area would have had a regional W-NW to NW trend being segmented by minor NE structures. Both sets were reactivated during Andean times, acting W-NW and NW structures as transfer zones between decoupled contractional panels and NE structures as frontal contractional structures. N-S contractional structures did not respect rifting architecture cutting through the depocenters and occasionaly exhuming synextensional geometries.
\end{abstract}

Keywords: Synextensional sedimentation, Late Triassic, rifting, Northern Neuquén Precordillera, Andes

Resumen

La combinacion de datos de campo, junto con magnéticos y gravimétricos, revelan un patrón complejo de estructuras sobreimpuestas al orógeno gondwánico (Carbonífero superior- Pérmico) en el sector interno de la faja plegada y corrida de los Andes Centrales australes, en el área de la cordillera del Viento.

Estructuras de basamento W-NW, NW de significancia regional, segmentadas por estruturas menores NE están limitando depocentros y altos estructurales correspondientes al rifting del Triásico Superior de la cordillera del Viento, equivalente de las unidades del ciclo Precuyo.

En el campo se reconoce además un patrón de estructuras de rumbo $\mathrm{N}$, asociadas a fallas andinas que no muestran evidencias de un control estrutural previo, ya que las anomalías magnéticas están cortadas por éstas. Las observaciones de campo demuestran que tanto las estructuras W-NW y NW como las NE controlan cambios de espesor de los sedimentos del Triásico Superior y se asocian a geometrías sinextensionales. El modelo propuesto indica que el rifting del Triásico Superior podría haber tenido una geometría elongada según el patrón de estructuras identificadas W-NW a NW, segmentado por estructuras menores NE. Ambas muestran reactivación durante tiempos andinos, las primeras actuando como zonas de transferencia entre sectores que muestran diferentes grados y mecánicas de contracción y las últimas como estructuras frontales contraccionales. Las estructuras contraccionales de orientación N-S no respetan la arquitectura del rift triásico, cortando los depocentros y eventualmente exhumando geometrías sinextensionales.

Palabras clave: Sedimentacion sinextensional, Triásico Superior, extension continental, Precordillera Neuquina Norte, Andes 


\section{Introduction}

Several studies during the past years have pointed out the relationship that exists in the southern Central Andes between i) Late Triassic rifting, derived from the Gondwana break up, and synchronous sedimentation; and ii) Andean structures as the result from their inversion. However, only few of them have documented these controls through a detailed mapping (see Rodríguez Fernández et al., 1997; Bechis et al. 2010).

One of the places to address the potential control that exerted previous extensional structures in the development of Andean deformation is the western sector of the Chos Malal fold and thrust belt (Fig. 1). Here, the last stage of the Gondwanic cycle (late Carboniferous - Early Permian) (see Giacosa et al., this volume), is well represented in the western slope of the cordillera del Viento up to the Early to Middle Triassic volcanic-plutonic Huinganco complex, equivalent to the Choiyoi group. The end of this cycle has been identified with the development of an undulated erosion surface known as the Huarpician unconformity (Azcuy and Caminos 1987; Llambías et al., 2007). This regional unconformity represents the transition between the Permian volcano-plutonic complex (Choiyoi Group) to the Late Triassic rifting stage in the re- gion. This Late Triassic extensional stage affected the protoPacific Gondwana margin for 30 Ma until the Early Jurassic. (see Charrier et al., 2007 for a recent discussion). Since then, this region experienced thermal subsidence for more than 80 Ma forming a large embayment in the region known as the Neuquén basin, until the beginning of the Andean orogenesis when sedimentation patterns changed (Fig. 1). Initial extension resulted in a series of depocenters orthogonally and obliquely oriented respect to the margin, filled with volcanoclastic and pyroclastic deposits associated with lava flows, ignimbrites and other related products (Franzese and Spalletti, 2001). This magmatism is represented by the Cordillera del Viento Formation (=Choiyoilitense sensu Groeber, 1946) which had a bimodal signature consistent with this extensional regime (Franzese and Spalletti, 2001; Llambías et al., 2007).

Even though basin architecture has been relatively well constrained by seismic records and well logs (Legarreta and Gulisano, 1989; Vergani et al., 1995; Manceda and Figueroa, 1995), few studies have analyzed that from field surveys (Rodríguez Fernández et al., 1997; Cristallini and Ramos, 2000; Bechis et al. 2010). These studies demonstrated that Late Triassic rift systems are mostly elongated, segmented by minor structures outlining depocenters with contrasting depths, go-

$75^{\circ} \mathrm{W} \quad 73^{\circ} \mathrm{W}$
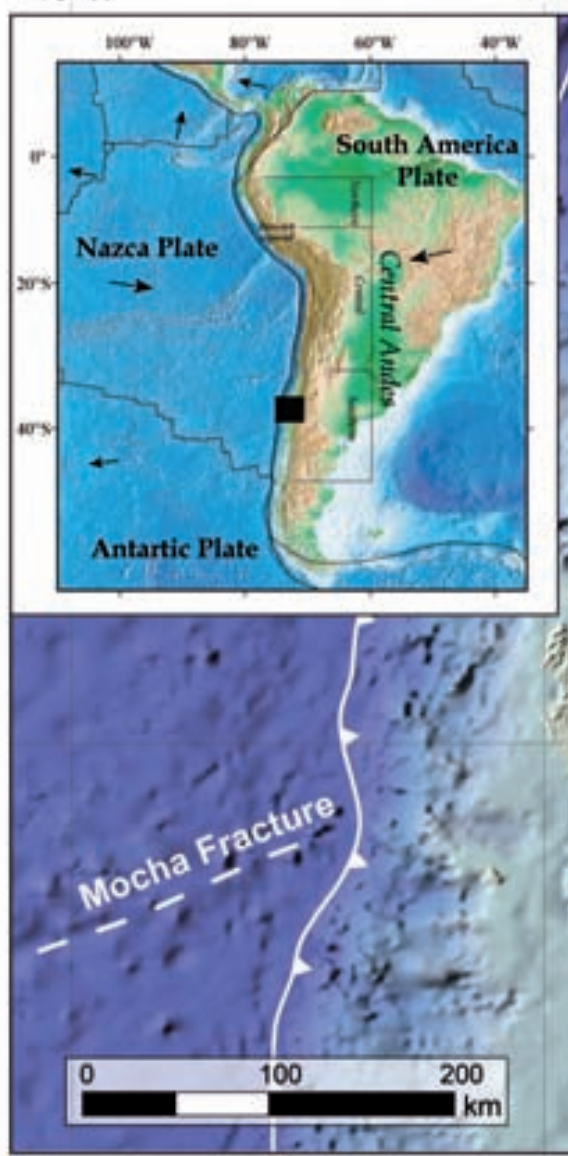

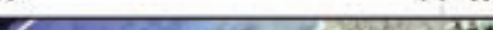

$71^{\circ} \mathrm{W}$

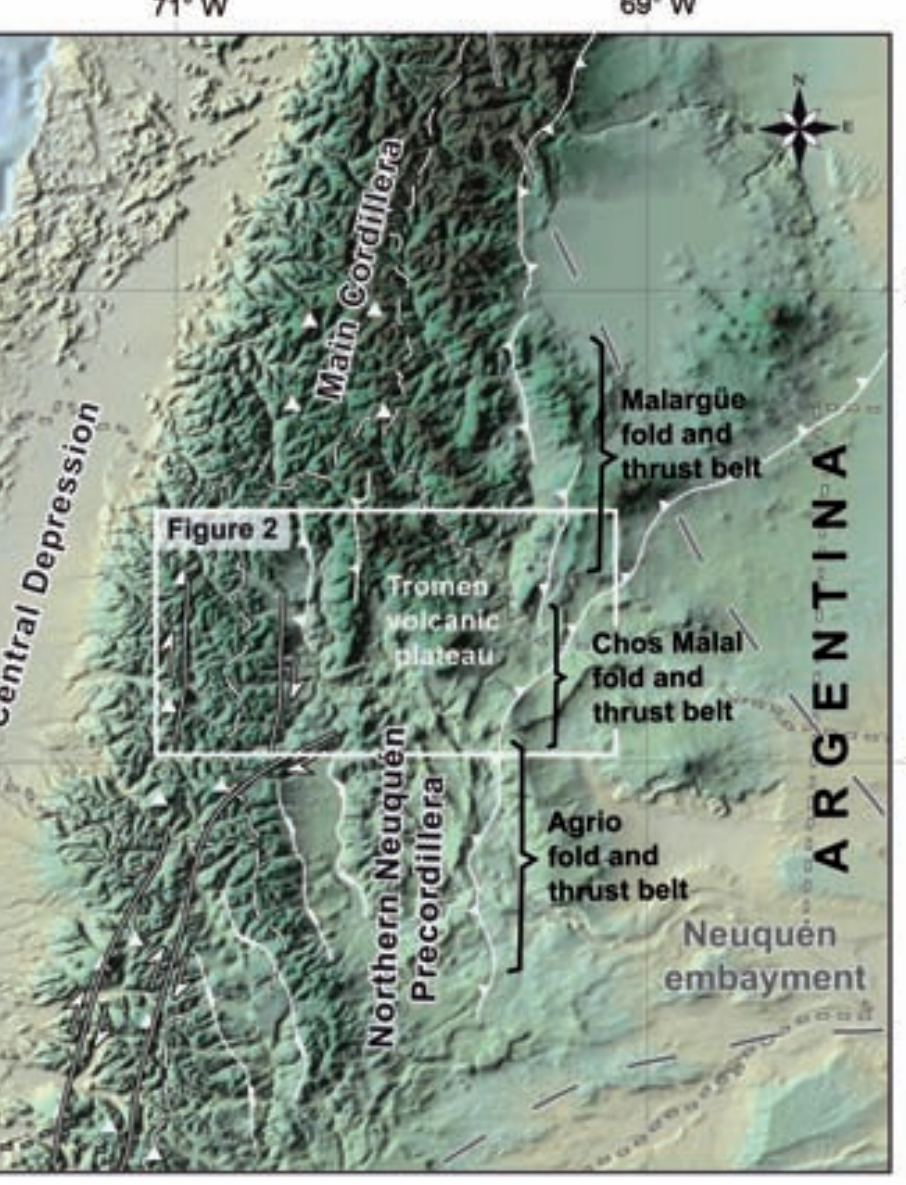

Fig. 1.- Main morphostructural units in the study area, located in the northern Neuquén Precordillera at the western part of the Chos Malal fold and thrust belt. The Cordillera del Viento is the only structure in this area that exposes the Paleozoic polyorogenic basement. 


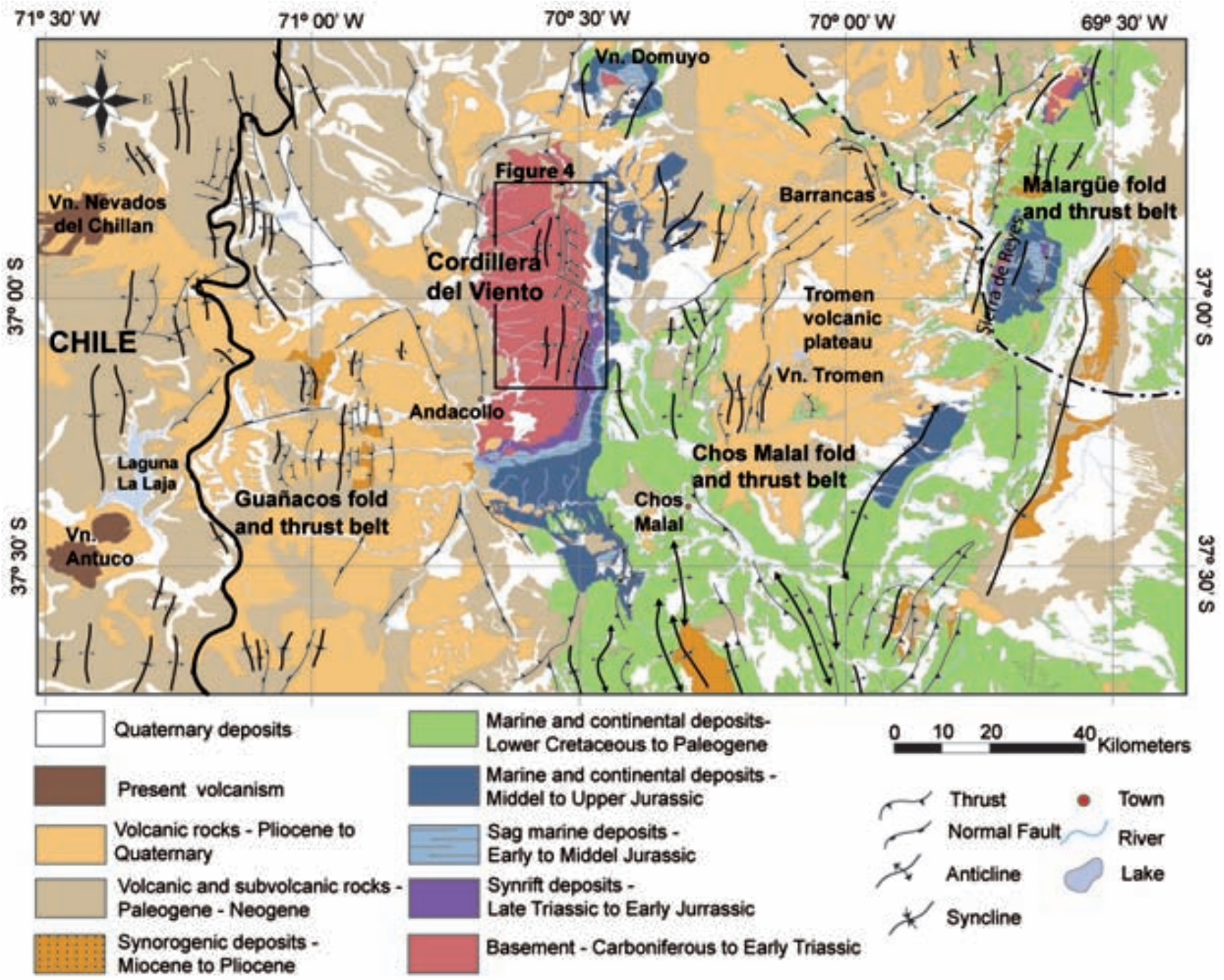

Fig. 2.- Geology of the study area. The Cordillera del Viento lies between the Main Cordillera of the Andes and the Chos Malal fold and thrust belt (northern Neuquén Precordillera). The Main Cordillera is surficially composed of Paleogene to Neogene volcanic and subvolcanic rocks uncomformably overlain by Pliocene to Quaternary arc rocks. The northern Neuquén Precordillera is formed by Mesozoic sedimentary sequences from Early Triassic to Late Cretaceous interrupted by the Cordillera del Viento basement block (anticlinorium), exposing Devonian and Carboniferous to Early Triassic rocks.

ing locally from $2.000 \mathrm{~m}$ to more than $4.000 \mathrm{~m}$ (see Pángaro et al., 2011 for a recent synthesis). In these surveys, listric normal faults with commonly half-graben geometry are considered the common structure that control individual depocenters.

However, recent studies show an increased internal complexity of these depocenters. Bechis et al. (2010) through a detailed kinematic analysis of the Atuel depocenter further to the north $\left(34^{\circ} 50^{\prime} \mathrm{S}\right)$, determined an $\mathrm{N} 10^{\circ} \mathrm{W}$ orientation for the rift shoulders produced under a NE regional extensional field. In addition, these studies recognized at least three other minor orders of faults that internally segmented the extensional architecture of the depocenter (Giambiagi et al., 2008; Bechis et al., 2010).

At the northern part of the Northern Neuquén Precordillera, where this study is located (Fig. 2), previous works had proposed that the Late Triassic depocenters were dominantly $\mathrm{N}$ to NW oriented (Uliana et al., 1989; Vergani et al., 1995; Franzese and Spalletti, 2001; Spalletti, 1997; Yagupsky et al., 2008). Here, the Cordillera del Viento -cerro Domuyo areas (Fig. 2), corresponding to the major basement Andean uplifts of the fold and thrust belt at these latitudes, exhume Late Triassic sections through east-verging N-S oriented structures (Kozlowski et al., 1993).

Since the '90s the Cordillera del Viento, which exposes the deepest structural levels in the whole Malargüe-Chos Malal and Agrio fold and thrust belt (Fig. 2), had been related to the tectonic inversion of Late Triassic normal faults (Vergani et al., 1995; Zapata et al., 1999; Zamora Valcarce et al., 2006). Those models assumed a rather simplistic geometry in which a single half-graben depocenter was inverted. However, no detailed evidences of such a model are available. This study 
is the first detailed mapping that reflects extensional controls in the Late Triassic successions for this area, yielding a much more complex rifting architecture than previously assumed. Field observations are contrasted with new terrestrial and airborne-gravity and aeromagnetic data that allow interpreting this complex structural pattern at depth. Finally, the role of previous normal faults is discussed in relation to Andean structures in the area.

\section{Geological setting}

The study area is characterized by a series of morphostructural domains that are the result of a complex evolution since the construction of the Gondwana margin to the development of the Main Cordillera of the Andes in the last $100 \mathrm{Ma}$ (see Ramos et al., 2011 for a recent synthesis). From west to east, the Cordillera de la Costa is characterized by metamorphosed rocks related to the obduction of an accretionary prism intruded by arc-related rocks (see Charrier et al., 2007 for a recent synthesis). The Central Depression consists of a thick Quaternary-Cenozoic volcanoclastic basin that records periods of stretching and contraction that affected the South American margin (Araneda et al., 2000; Farias et al., 2008). To the east, the Main Cordillera, where the volcanic arc is emplaced, is constituted by Jurassic-Cretaceous to Paleogene sections exposed over a deep decollement. Finally, over the eastern Andean slope in the retroarc area, the Northern Neuquén Precordillera is developed, where the Malagüe, Agrio and Chos Malal fold and thrust belts are located (Fig. 2 ). These systems can be differentiated by their contrasting amplitude and associated structural levels. In particular, the Malargüe fold and trust belt to the north exposes basement rocks in the orogenic front that is located further to the east in comparison to the orogenic front to the south (Fig. 1) (Kozlowski et al., 1993). This system and the Chos Malal fold and thrust belt to the south, were formed in three contractional pulses, the first occurring in Late Cretaceous, the second in the Paleocene, and the last in early to middle Miocene times (Cobbold and Rossello, 2003; Silvestro and Atencio, 2009; Tunik et al., 2010; Orts et al., 2011). However, the Chos Malal orogenic front is considerably retracted to the west in comparison to the northern segment. Both sectors show broad areas semi-covered by Miocene arc-related rocks, deformed in late Miocene times, and absent to the south (Ramos and Kay, 2006). The Agrio fold and trust belt is characterized by a dominant Late Cretaceous pulse of deformation (Zamora Valcarce et al., 2006), and a lower structural relief associated with a consequently highly eroded topography. In this southern section, prominent structures that expose the basement, are circumscribed to the western part (Fig. 2). These structures transfer to the east contractional deformation to the sedimentary cover, not exposing basement rocks at the orogenic front area (Ramos, 1998; Zapata et al., 1999; 2002).
Particularly, the region of interest lies in the western part of the Mesozoic Neuquén Basin, and is part of the Chos Malal fold and thrust belt in the northern Neuquén Precordillera (Fig. 2). The most prominent basement structure is the Cordillera del Viento that exposes the entire section of the Neuquén basin, from the Late Triassic to the Neogene infill (Fig. 2). This feature shows the best basement exposures of the Neuquén basin. The Cordillera del Viento is divided into i) a highly deformed and metamorphosed pre- Carboniferous Chanic basement (Zappettini et al., 2012, Giacosa et al., this volume), ii) a very low grade to non metamorphic Gondwanan basement (Andacollo Group), formed by volcanic and sedimentary marine rocks of Carboniferous age (Giacosa et al., this volume), intruded by Permian granites (volcanic - plutonic Huinganco Complex) that are covered unconformably by iii) Late Triassic volcanic rocks equivalent to the Precuyo cycle (Llambías et al., 2007; Leanza et al., 2005). The Cordillera del Viento range was uplifted during pre-Oligocene times, through the inversion of Late Triassic - Late Jurassic normal faults and the activity of newly created contractional structures (Zapata et al., 1999; Zamora Valcarce and Zapata, 2005; Burns et al., 2006; Zamora Valcarce et al., 2006; 2009). This basement structure has produced locally thin-skinned deformational belts to the east, represented by complex structures detached in marine sediments of the Auquilco-Vaca Muerta Formations (Middle to Late Jurassic - Early Cretaceous), and of the Huitrin Formation (Early to Late Cretaceous). Finally, a late contractional reactivation of this structure took place in late Miocene times (Llambías et al., 1978; Folguera et al., 2007).

\section{Eastern flank and axial zone of the Cordillera del Viento}

The eastern flank of the Cordillera del Viento shows the clearest evidence of synextensional sedimentation for the Late Triassic successions (Fig. 3). Detail mapping of the geology and the structure of this region provides accurate descriptions of the synextensional packages and their relation to the structure.

Llambías et al. (2007) and Giacosa et al. (this volume) summarized the stratigraphy of the studied region based on new data and a compilation of previous works. The oldest litostratigraphic unit of the Cordillera del Viento is the metasedimentary Guaraco Norte Formation (Zappetini et al., 1987, Giacosa et al., this volume) that is exposed in a single outcrop in the northwestern flank of the Cordillera del Viento, out of the study area (Giacosa et al., this volume). The Guaraco Norte Formation is composed of quartz-rich metasandstones and finely laminated quartzite layers and slates, cut by numerous quartz and granitic veins. U-Pb SHRIMP dating confirms partly an Upper Devonian age, yielding a maximum depositional age of $374 \mathrm{Ma}$ and $389 \mathrm{Ma}$ (Zappettini et al., 2012). The Guaraco Norte Formation was deformed 
and metamorphosed in Late Devonian - early Carboniferous times by the Chanic orogeny (Giacosa et al., 2014).

The Guaraco Norte Formation is unconformably covered by the volcanic-sedimentary rocks of the Andacollo Group, which crops out largely in the axial zone of the Cordillera del Viento anticline (Fig. 4). The Andacollo Group consists of $2.100 \mathrm{~m}$ of tuffs and rhyolitic-lava flows in the lower part that upwardly passes to quartz sandstones and marine shale sediments (Zöllner and Amos, 1973; Digregorio and Uliana, 1980; Llambías et al., 2007). Igneous zircons in a rhyodacitic dome with fluidal texture, intruded in ignimbrites of the lower part of this formation, were dated at $327,9 \pm 2.0 \mathrm{Ma}(\mathrm{U}-\mathrm{Pb}$ SHRIMP), which allows assigning an early Carboniferous age for the basal part of the Andacollo Group (Suárez et al., 2008). Invertebrate marine (brachiopods) and plant fossils
(Rhacopteris) (Amos, 1972; Zöllner and Amos, 1973) identify the upper part as late Carboniferous. The Carboniferous Andacollo Group was folded during the late Carboniferous Early Permian by the San Rafael orogenic phase and intruded by lower Permian to lower Triassic rhyolitic-granodioritic dikes and domes. This volcanic - plutonic complex is considered to be an equivalent of the Choiyoi Group, with $\mathrm{K} / \mathrm{Ar}$ ages yielding $260 \pm 10,287 \pm 9$ and $259 \pm 18 \mathrm{Ma}$ (Llambías, 1986; JICA, 1992; Suárez and De la Cruz, 1997), and U-Pb ages of 283,4 $\pm 1 \mathrm{Ma}$ (Sato et al., 2008).

This intrusive-extrusive suite and the other Paleozoic rocks are uncomformably covered by the Triassic Cordillera del Viento Formation, which occupies broad sectors of the study region (Figs. 3 and 4). This unit was considered originally as part of the Choiyoi Group by Rolleri and Criado

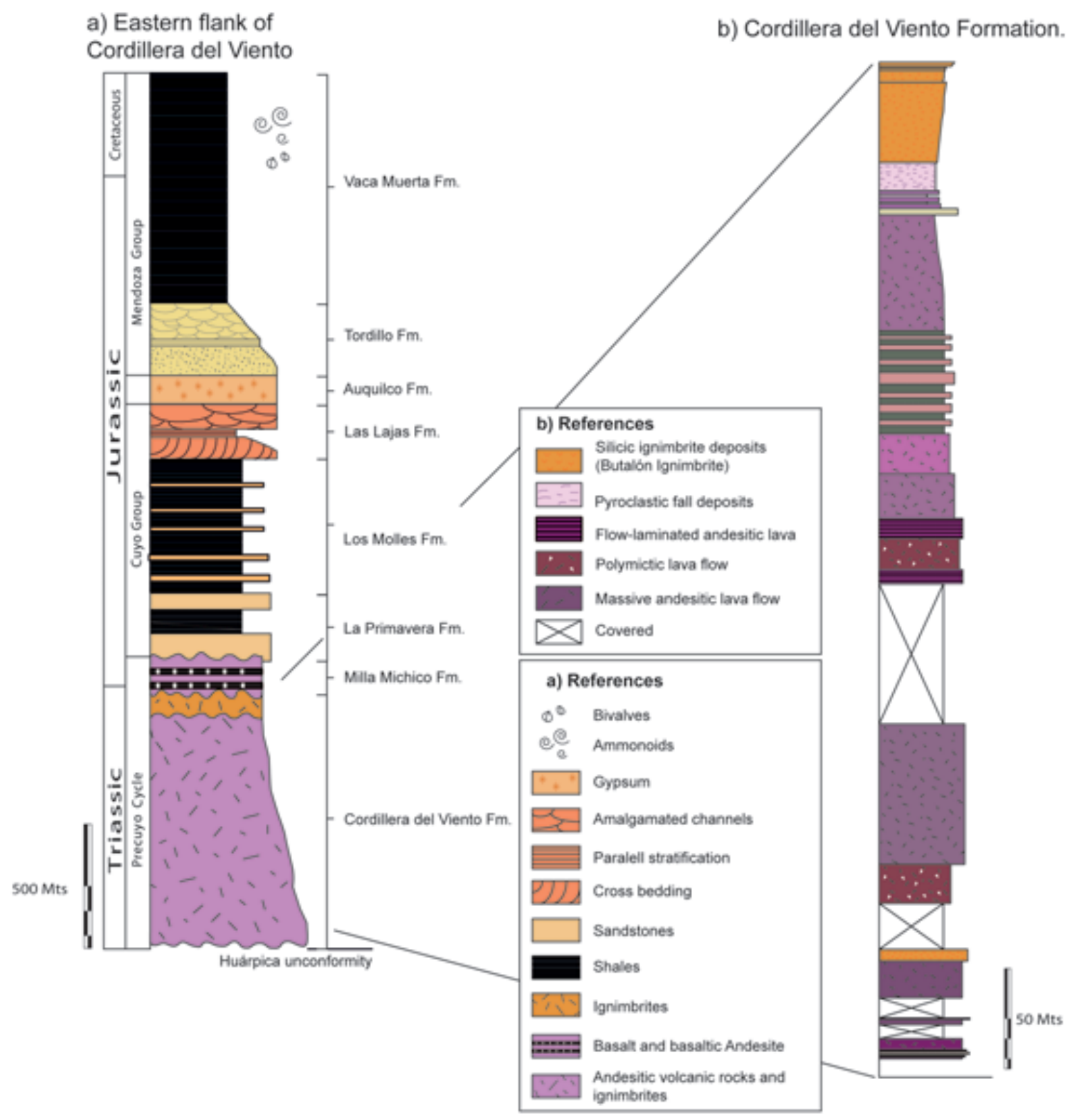

Fig. 3.- Stratigraphic column of the Cordillera del Viento. a) Sequences exposed in the eastern slope of the Cordillera del Viento. b) Detailed section of the upper part of the Cordillera del Viento Formation where synextensional features were described (see text for details). 


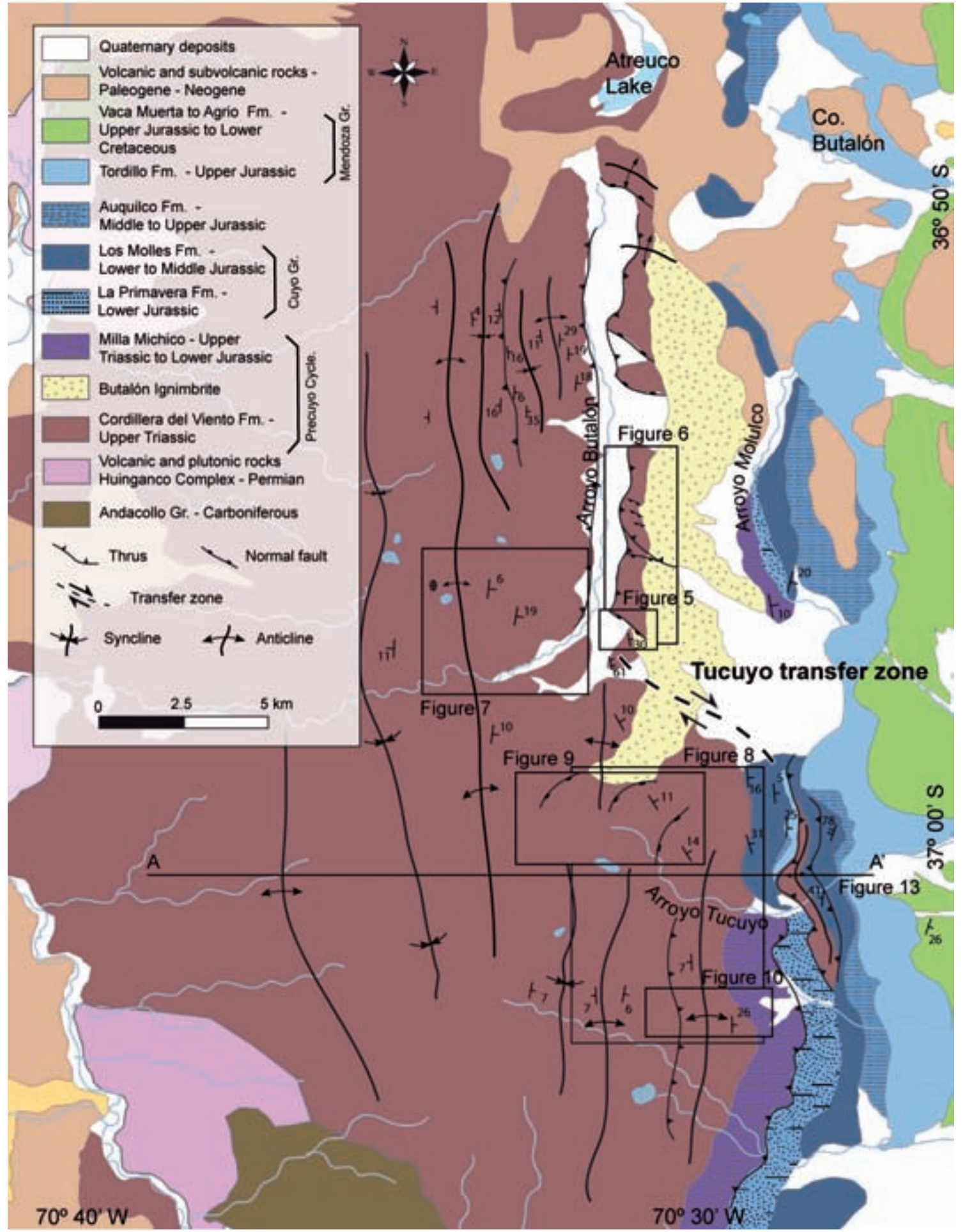

Fig. 4.- Geological map of the eastern slope and axial zone of Cordillera del Viento. Synrift and sag deposits of the Neuquén basin are exposed at its eastern slope (Milla Michicó Formation, Cuyo Group, Auquilco and Tordillo Formation; Llambías et al., 2007; Leanza et al., 2005; Folguera et al., 2007).

Roque (1970), although Llambías et al. (2007) and Zanettini et al. (2001) through detailed descriptions correlated it with the Precuyano Cycle (Figs 3 and 4). The Cordillera del Viento Formation is formed by conglomerates and fanglomerates in the lower part, that pass to sandstones and finally andesitic-lava flows interbedded with rhyolitic ignimbrites and andesitic sills, highlighting the bimodal character of the sequence (Leanza et al., 2005; Llambías et al., 2007). This formation is at least $2.000 \mathrm{~m}$ thick and constitutes the focus of this study.

A detailed sedimentary profile was surveyed in the upper part of this unit (Fig. 3b), where a synextensional character 
is identified. The whole section is constituted by reddish and greenish massive packages of volcanic rocks. Ignimbrites and volcaniclastic rocks with volcanic, sedimentary and lithic phenocrysts predominate upwardly (Fig. 3).

In detail, the first $50 \mathrm{~m}$ are represented by massive packages of lava flows with quartz and potassium feldspar as phenocrysts interbedded with thin ignimbritic levels with low proportions of fiammes at the top. These rocks are covered by $300 \mathrm{~m}$ of lava flows with plagioclase, potassium feldspar, and quartz as phenocrysts. On top there are $110 \mathrm{~m}$ corresponding to four upwardly coarsening ignimbritic pulses interbedded with lava flows (Fig. 3). This section ends with a massive ignimbrite section of variable thickness that is mapped as a non-formal unit (Butalón ignimbrite) because of its important surface development crowning the main hills in the region (Fig. 4).

These strata are uncomformably covered by a succession of shales $200 \mathrm{~m}$ thick of the Milla Michicó Formation (Leanza et al., 2013; Leanza et al., 2005; Llambías et al., 2007). The type locality of this unit is at the southern slope of the Cordillera del Viento range, where Upper Triassic to possibly Lower Jurassic mesosilicic to basic volcanics are exposed, displaying a bimodal character (Llambías et al., 2007; Leanza et al., 2011). This unit is unconformably overlain by the basal terms of a Lower Jurassic marine transgression represented in this area by the La Primavera Formation (Fig. 3) (Llambías et al., 2007).

\section{Evidence of synextensional sedimentation in Late Triassic units}

A detailed examination at the volcaniclastic sections of the Cordillera del Viento Formation through the core of the homonymous range shows evidence of synextensional sedimenta- tion. Figure 5 illustrates dip changes through the arroyo $\mathrm{Bu}-$ talón section describing a fan of progressive unconformities, typically steeper in the lower section than towards the upper terms. These growth fans are recognized at different scales, being systematically associated to inverted and non-inverted normal faults (Fig. 6).

Figure 5 shows the two superimposed different scales: In the foreground is shown a decimeter profile, with a dip range going from $61^{\circ} \mathrm{E}$ to $32^{\circ} \mathrm{E}$, while at the background a much larger fan of progressive unconformities is coring the axial zone of the Cordillera del Viento. The smaller fan coarsens in a NE direction towards the normal fault displayed in Figure $6 \mathrm{~b}$, while the bigger fan behind opens towards the Arroyo Butalón fault (Figs. 5 and 6).

Along the Butalón valley, a roughly N-S west facing scarp exposes a series of volcano-sedimentary depocenters $600 \mathrm{~m}$ thick with synrift geometry in direct relation to NW extensional faults (Figs. 5 and 6). These extensional depocenters are selectively inverted showing the extensional architecture as a series of grabens and horts of 500-400 $\mathrm{m}$ in amplitude individually. Those are inverted through combined mechanisms that involve inversion of normal faults and also through primary reverse faults cutting through the syn-extensional fillings (Fig. 6). Additionally, these structures are exposed through a backthrust that determine a triangular zone together with the east-vergent Arroyo Butalón fault along the upper Butalón valley (Fig. 7a).

The Arroyo Butalón fault exposes the east-broadening synextensional fan shown in figure 5 that is openly folded in an antiform that form the axial part of the Cordillera del Viento range. Internally, this structure is refolded into a series of 1-2 $\mathrm{km}$ anticlines and synclines (Fig. 7b). Those, developed at the core and frontal/eastern limb of the big structure, show Late Triassic sections separated and truncated by a series of minor

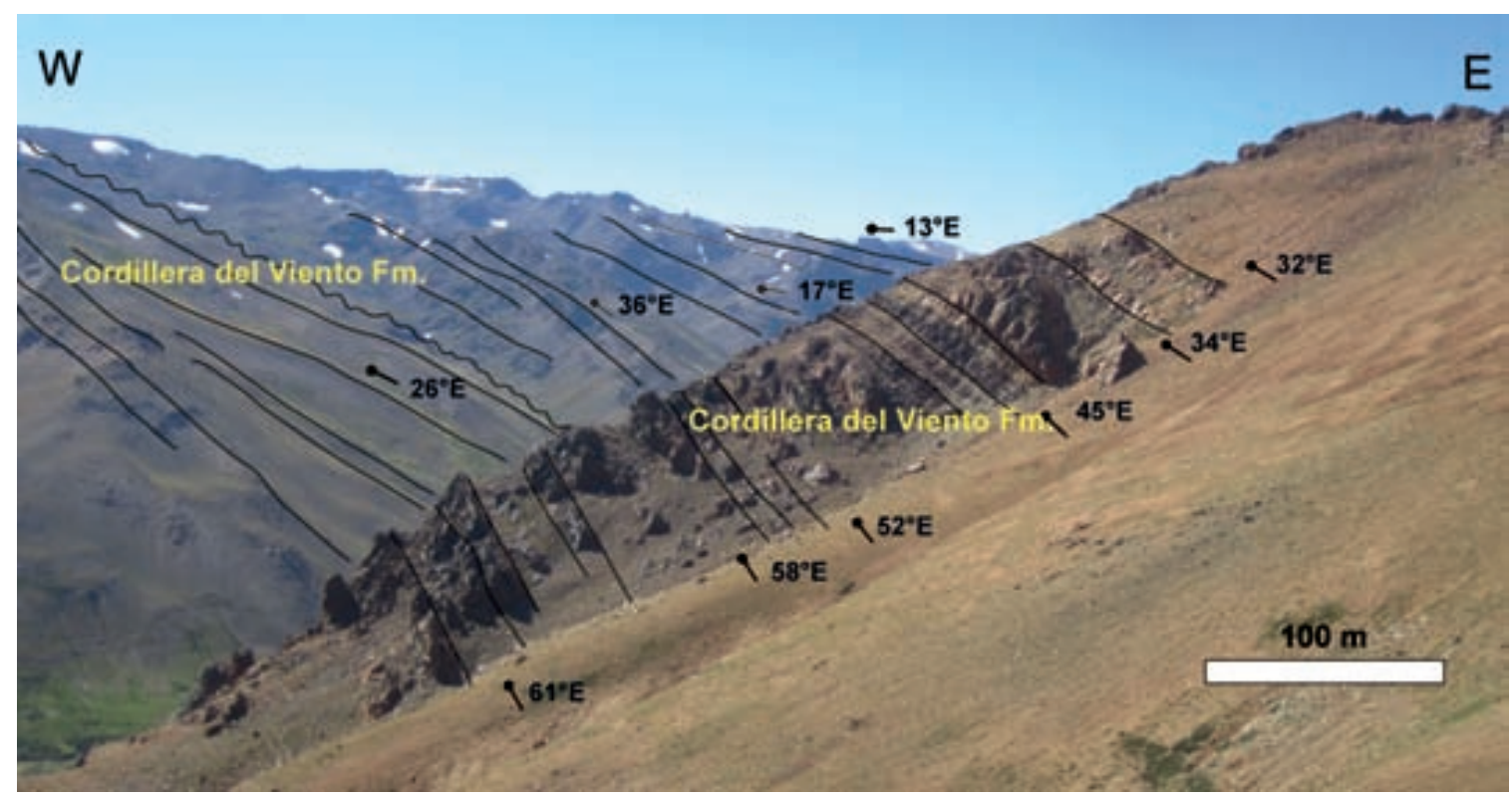

Fig. 5.- Synrift geometries in the Cordillera del Viento Formation, in the northern part of the Cordillera del Viento uplift (see Fig. 4 for location). The Butalón synrift constitutes the main depocenter exposed at the axial part of the cordillera del Viento. 

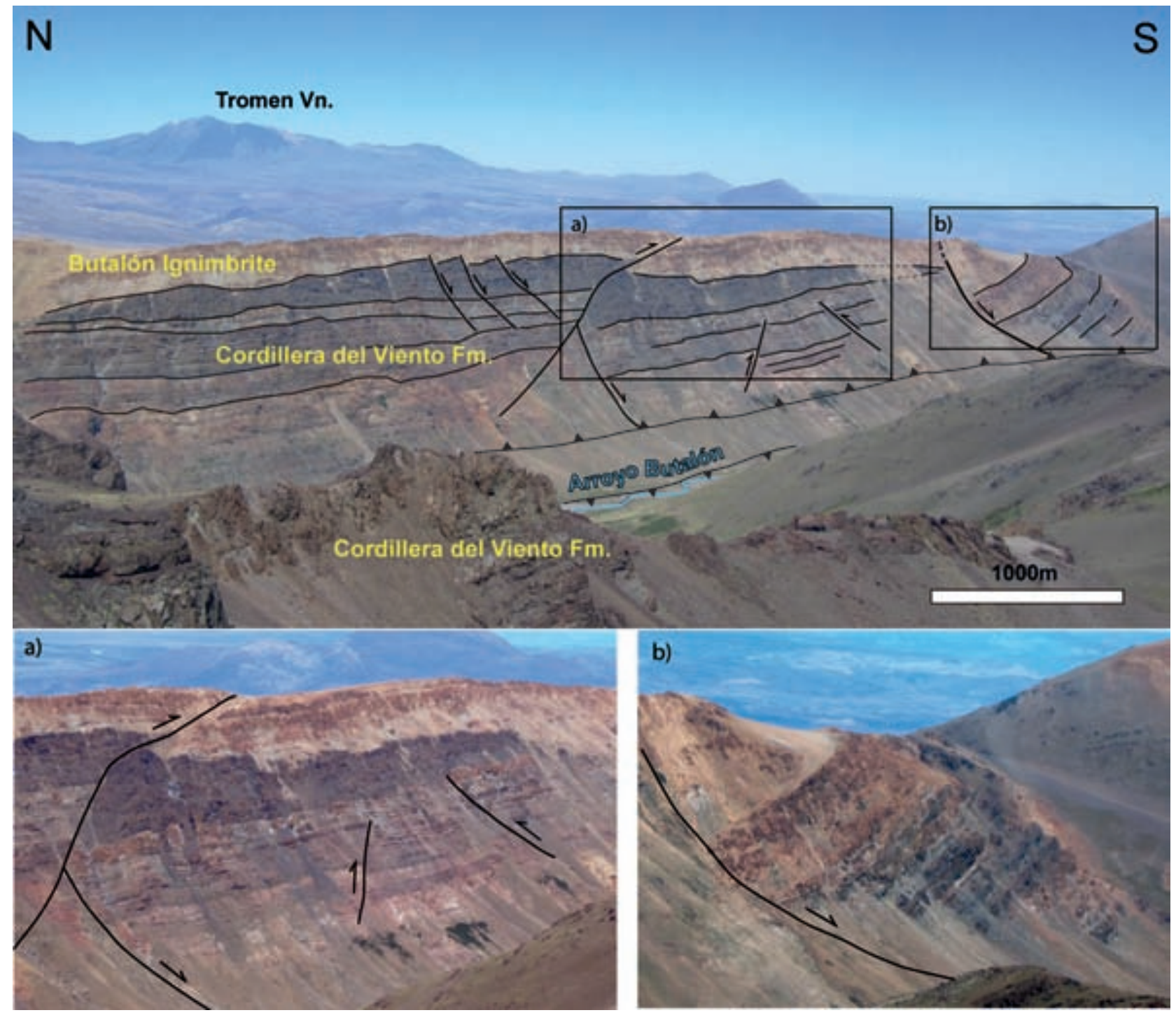

Fig. 6.- East view of the main structures in the northern Cordillera del Viento high, defining a triangular zone between two reverse faults with opposite polarities exposing the Cordillera del Viento Formation. Note a second order set of structures segmenting the bigger depocenters that correspond to a series selectively inverted half-grabens (see Fig. 4 for location). a), b) Zoom in focused on main structures.

unconformities interpreted as caused by sedimentation coetaneous to rotation during activity of normal faults (Fig. 7 b).

To the south, next to the arroyo Tucuyo (Fig. 5), the Cordillera del Viento Formation is preserved in small-scale depocenters associated with NE normal faults (Figs. 8 and 9). This valley seems to run through a structure since both sides of it show contrasting structural levels (Fig. 8). While the northern margin of the valley, shows typical synextensional features related to normal faults, the opposite margin, shows the uppermost sections folded with a clear west-vergence resulting from the inversion of the previous fault array (Figs. 8 and 9).

Additionally, the frontal eastern thrust of the Cordillera del Viento at these latitudes exposes a more than $1.400 \mathrm{~m}$ thick section describing a synextensional structure of a bigger scale (Fig. 10), similar to the one exposed west of the Butalón valley. This feature broadens in the opposite direction that the minor western synrift packages (Fig. 11). Therefore, the extensional structure south of the Tucuyo valley shows a synrift depocenter displaced to the east respect to the NW extensional architecture to the north, clearly decoupled by the Tucuyo fault that would work as a transfer zone, segmented by minor NE extensional faults (Figs. 4 and 11). This frontal thrust front even when exhumes a synrift package does not show a clear relation to an inverted normal fault (Fig. 11).

\section{Use of potential methods to study basement structure in the Cordillera del Viento}

Aerogravimetric, aeromagnetometric, and terrestrial data were surveyed in a wide zone surrounding the study area. The Aerogravity Carson Company recorded airborne data during 2004-2005, in east-west lines and north-south crossing lines spaced in $2 \mathrm{~km}$ and $10 \mathrm{~km}$ respectively (Fig. 12). From this 
array a $6 \mathrm{~km}$ mean resolution can be achieved with an error of $\pm 5 \mathrm{mGal}$. This error is due to a low resolution of the gravity data associated with a $5.250 \mathrm{~m}$ medium flight height and introduced corrections related to different accelerations of the ship during the survey.

In relation to field data, a double-frequency topographic GPS (Global Positioning System) was used to obtain a reliable positioning for all measurements, with a $0,15 \mathrm{~m}$ error in each location. The altitude data for each station was obtained from a digital elevation model from the Shuttle Radar Topography Mission (SRTM, NASA). A Scintrex CG-3 Autograv
Gravity Meter was used to obtain gravity data, which consist of a number of daily loops, each of which begins and ends with readings at the same point (drift base) so the drifts can be monitored. The gravity anomalies were calculated based on the classic expressions (Blakely 1995). For the free air correction, a $0,310.5$

$0,3086 \mathrm{mGal} / \mathrm{m}$ was used, while for the Bouguer correction a density of $2,67 \mathrm{~g} / \mathrm{cm} 3$ was assumed (Hinze 2003). All the data were reduced to the theoretical gravity Geodetic Reference System (1971).

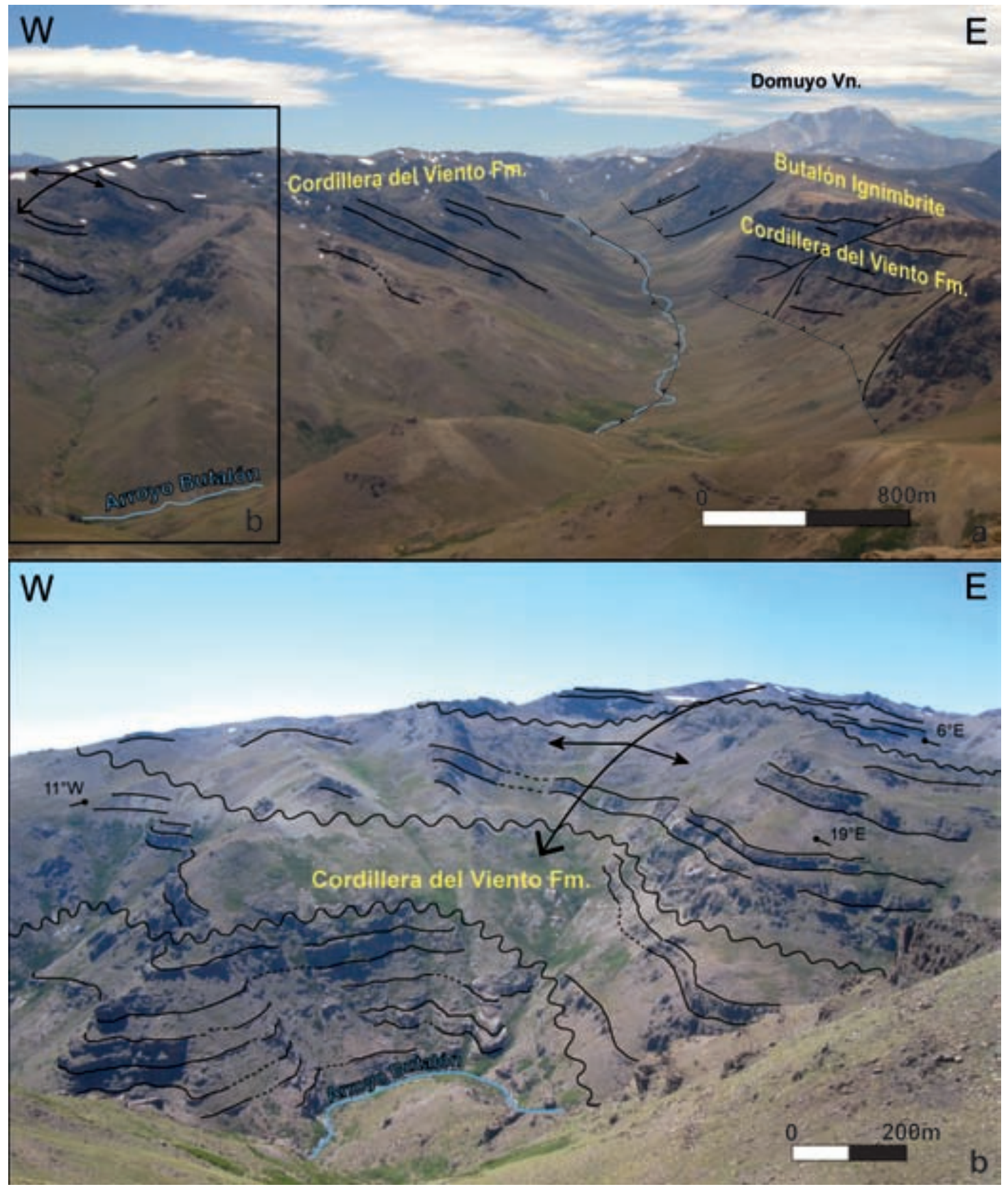

Fig. 7.- a) View to the north through the triangular zone in the Butalón valley. b) Detail of the axial part of the Cordillera del Viento, west of the triangle zone: In this section at least three unconformities are recognized, which are associated with a progressive broadening of the section eastwardly (see Fig. 4 for location). 

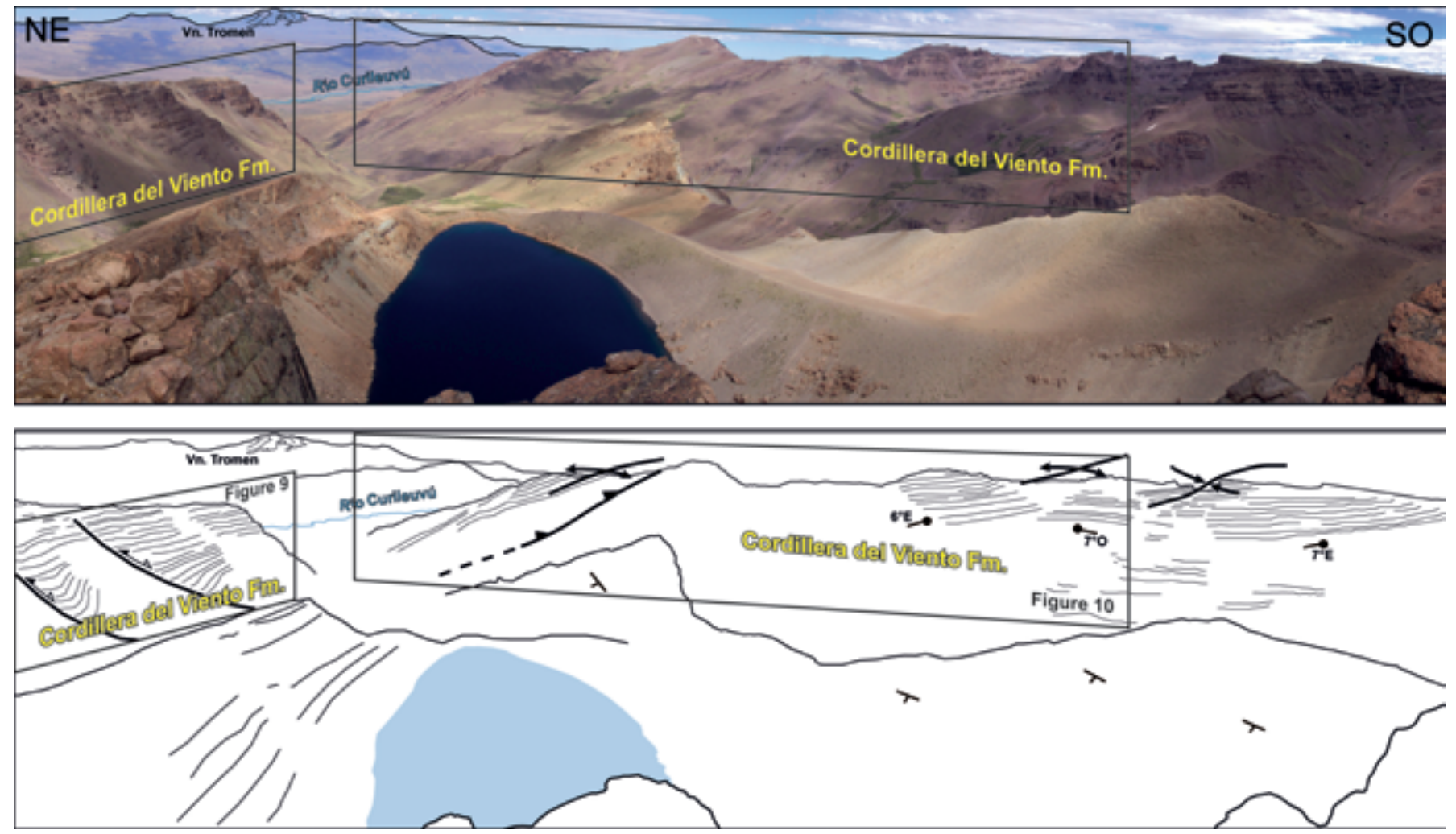

Fig. 8.- Panoramic view of the southern Cordillera del Viento High. Here the axial part of the range is segmented by a series of partially inverted half-grabens with opposite polarities respect to the main thrust front to the east (see Fig. 4 for location).

Since the target of this study was to analyze the geologic structures located on the upper crust, the long wavelengths were subtracted from the Bouguer anomaly. In order to do this, two methodologies with different bases but with very similar results were applied: 1) Upward continuation analyses and 2) Bandpass Filter. Among the different signalprocessing filters we chose the Butterworth filter in $250-\mathrm{km}$ window of order 8 (see Blakely, 1995), because it showed to be the most efficient tool in previous analysis with pronounced Andean crustal roots (Introcaso et al 1989; Gotze and Krause, 2002).

The results indicate a strong consistency between both residual datasets, with positive values on the cordillera del Viento, where the basement is exposed and negative on the Curileuvu valley, to the east, where a thick sedimentary cover is present (Fig. 12).

A basement model is displayed in Figure 13, which reflects computed depth of the pre-Neopaleozoic rocks that are supposed to constitute the main density contrast in the upper crust. These basement rocks are beneath the Triassic sections that show evidence of synextensional sedimentation and therefore its structure could give important clues about the rifting geometry. This $3 \mathrm{D}$ basement model is developed from filtered (residual) gravity anomalies and comprises a series of one or more layers, defined by grids, overlying a half-space (Parker, 1973). Each layer is assigned to a density value that is usually of $2,67 \mathrm{~g} / \mathrm{cm} 3$ for rocks immediately below the sur- face, $2,4 \mathrm{~g} / \mathrm{cm} 3$ for sedimentary rocks, and $2,75 \mathrm{~g} / \mathrm{cm} 3$ for basement rocks. These values are theoretical and are calculated from generic seismologic studies. The software utilizes fast Fourier transform (FFT) calculations to compute the model response (Popowski et al., 2006). The expanded grid inversion of the gravity field is calculated relative to a horizontal plane that in this work was at $2.500 \mathrm{~m}$ above sea level. The resulting gravity inversion computed from the Bouguer residual anomaly indicates how deep the top of the crystalline basement would be located assuming above mean densities (Fig. 13). This is considered a rough approximation, although it usually reflects interesting features that can be related to surface analyses.

The model shows that computed iso-depth basement contours are sensitive to described surface changes in structure amplitude (Fig. 4). North of the Tucuyo transfer zone, the inverted front of the cordillera del Viento (Butalón synrift; Figs. 5 and 7) lies relatively westward retracted, while to the south it expands eastwardly (Fig. 10). Computed basement contours follow those changes describing a stair-like geometry typical of inverted rift systems, constituted by frontal and lateral ramps (Fig. 13) (see Cristallini and Ramos 1996, for a local example). This geometry clearly reflects the structure of the cordillera del Viento thrust front at depth since data allow resolving features in the order of $6 \mathrm{~km}$ or more.

Magnetic data were also used to analyze basement segmentation in the area, at the same zone where field and gravity 

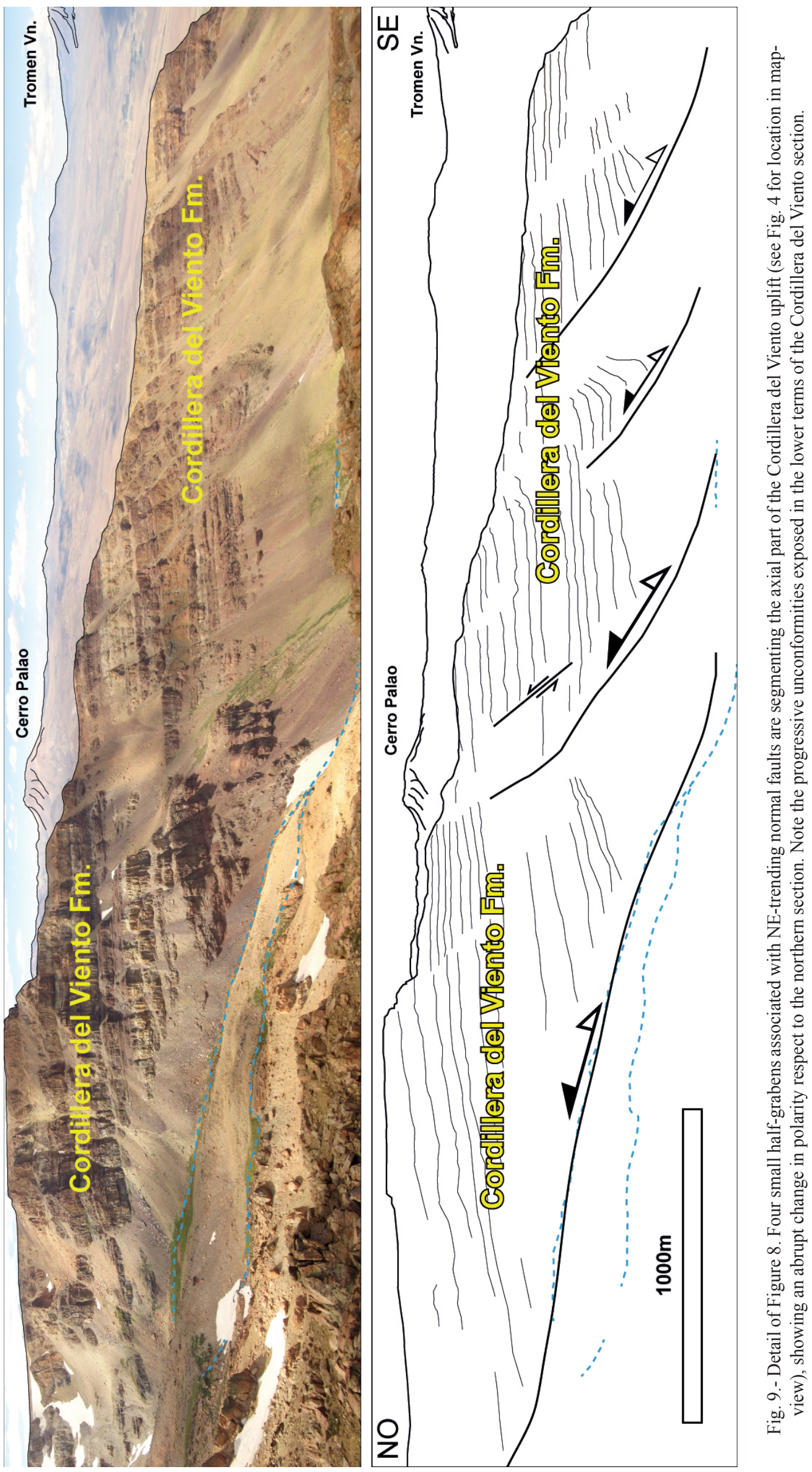

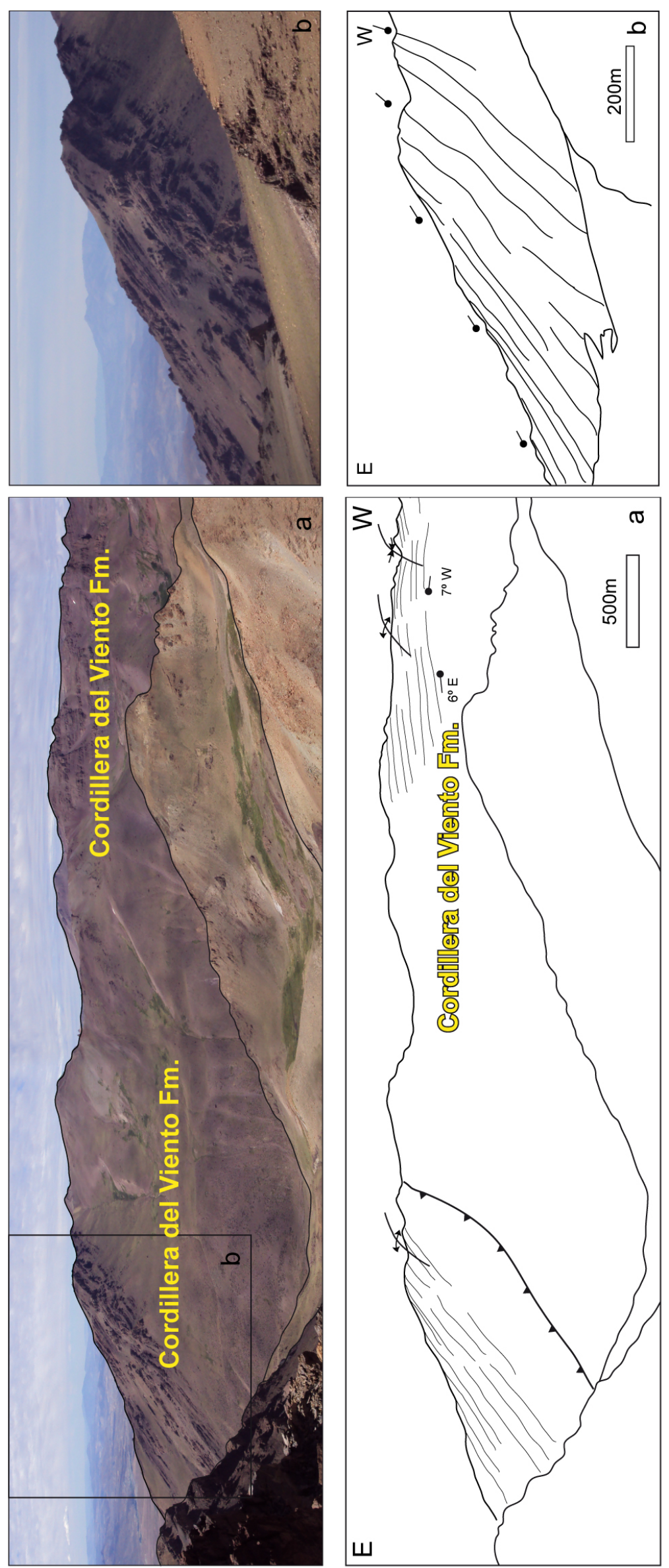

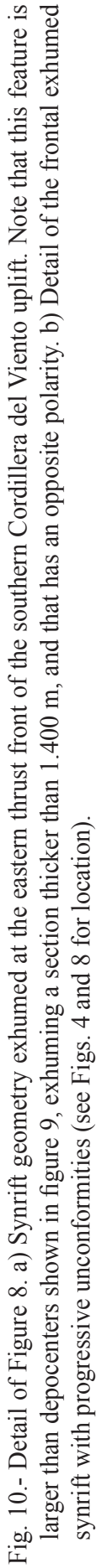




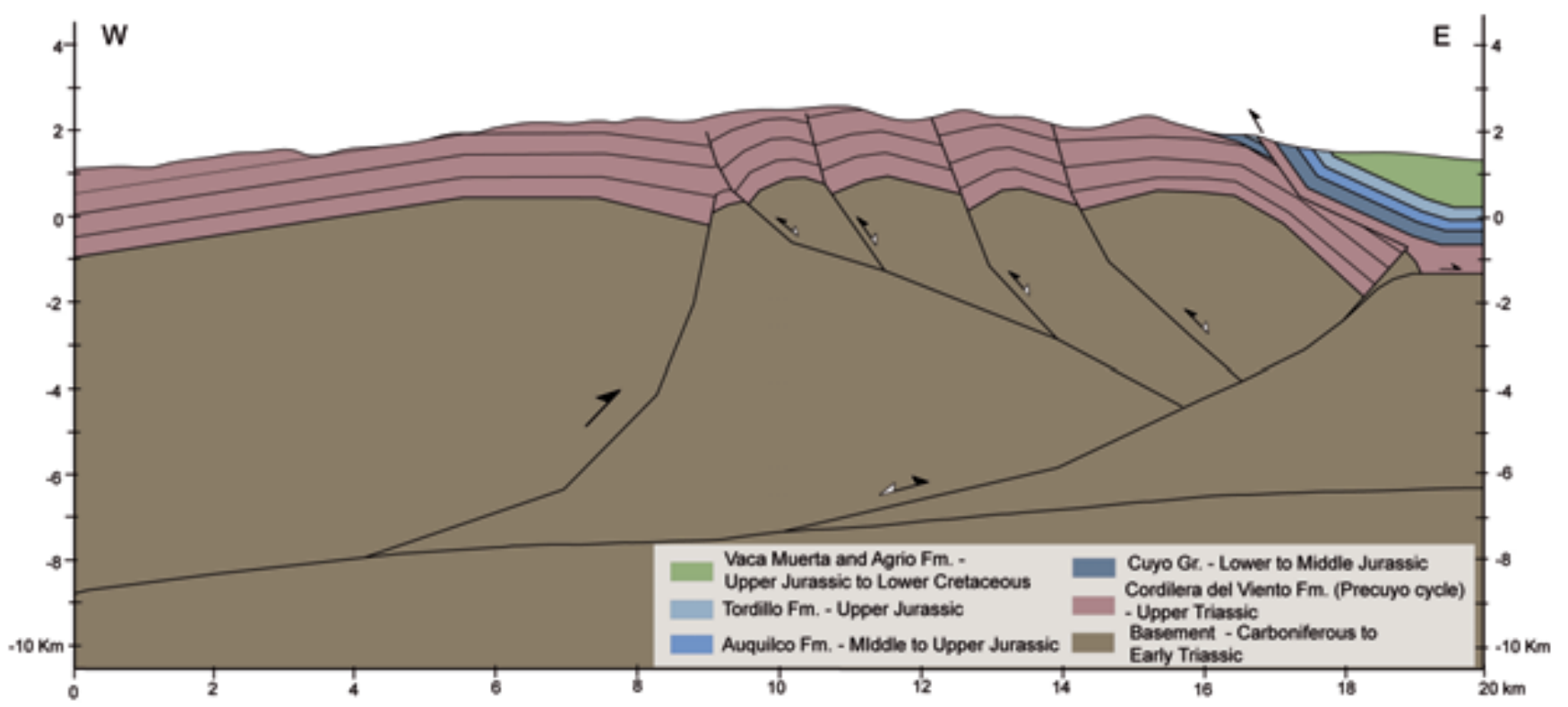

Fig. 11.- Structural scheme of the southern Cordillera del Viento uplift that shows a west-broadening synrift at the eastern thrust front (Fig. 10), segmented by minor antithetic normal faults (Fig. 9) partially inverted forming west-verging folds (see Fig. 4 for location).

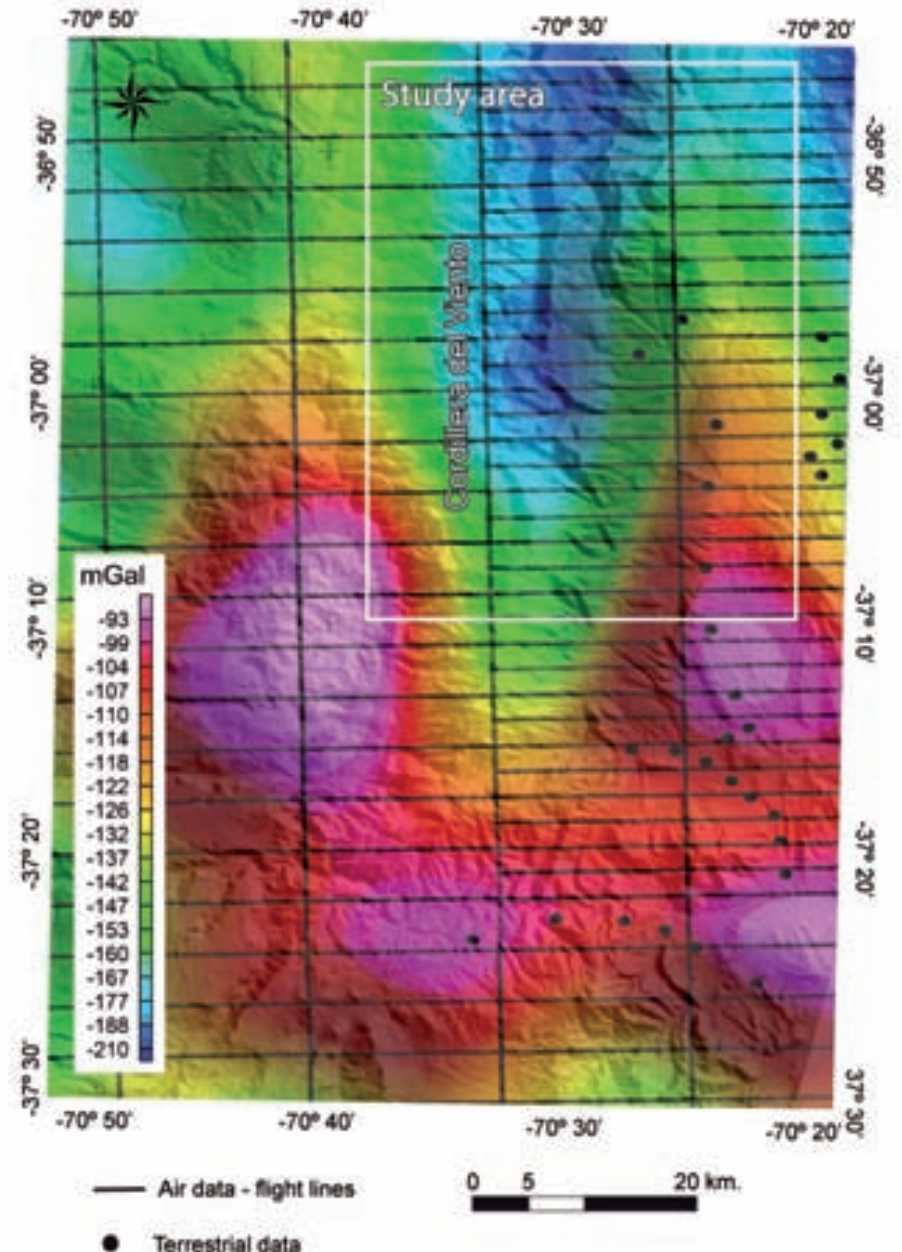

Fig. 12. - Gravity and magnetic dataset used in the present work. Flight lines are east-west spaced in $2 \mathrm{~km}$ while tie lines are north-south spaced in $10 \mathrm{~km}$. data were collected. We used a grid of total magnetic intensity data corrected for diurnal variation. This grid was compared with less dense terrestrial data mainly restricted to the surrounding areas. This comparison yielded an acceptable quality of aerial data and a wavelength resolution in the order of $500 \mathrm{~m}$ and $1 \mathrm{nT}$ of precision, sufficiently good for the analysis of basement segmentation.

Magnetic anomalies have, as a function of depth, wavelengths higher than the bodies with anomalous susceptibility that produce them. Therefore, in order to determine exact position of magnetic gradients at basement depth that could indicate fault contacts (basement topography), the analytic signal was calculated (Nabighian, 1972; Roest et al., 1992). This uses three perpendicular derivatives of the magnetic field, two in the horizontal and a third in the vertical. Thus, obtained patterns reflect more closely the real basement segmentation at depth that can be directly compared to field observations.

Two main lineal patterns were described, W-NW and NE oriented respectively (Fig. 14). Some W-NW lineaments interpreted in the analytic signal map coincide with the described Abra del Viento normal faults (Fig. 14). On the other hand, main contractional structures described in the field do not show a clear correlation to this pattern, cutting in most cases the basement architecture (magnetic pattern). Contrastingly, the Tucuyo transfer zone seems to be coincident with magnetic contours. A pattern of magnetic lows and highs is coincident with this fault zone, which is compatible with minor structures segmenting main depocenters (Fig. 6). As indicated previously, these smaller depocenters with $1-2 \mathrm{~km}$ size, can be effectively solved with this dataset that solves wavelengths up to $0,5 \mathrm{~km}$. 


\section{Discussion and conclusions}

The Cordillera del Viento locality has been identified as a classical example corresponding to tectonic inversion of Late Triassic normal faults, although related models are rather simplistic and not based on direct evidence. Our field-work through the axial and eastern zones of the Cordillera del Viento shows that main N- trending thrusts exhume synextensional geometries in Late Triassic sections, although they are not described in direct relation to normal faults. Moreover, internal architecture of those faulted blocks shows a pattern of segmentation defined by W-NW to NW and NE extensional structures that controlled variable thicknesses in these strata (Fig. 15).
W-NW structures are segmenting blocks with contrasting degrees and geometry of contractional deformation, acting probably as contractional transfer zones. In particular, the Tucuyo transfer zone defines a stair-like geometry in the eastern thrust front of the cordillera del Viento that is also noted in the basement inversion model derived from gravity data.

Computed gradients in magnetic data reveal this complex pattern of W-NW and NE nearly orthogonal structures segmenting the basement. W-NW to NW magnetic anomalies result in elongated highs and lows locally interrupted by shorter NE structures. No evident relationship exists between $\mathrm{N}$ - oriented contractional structures and magnetic anomalies, suggesting that those are cutting through the extensional architecture.
Fig. 13.- Basement iso-depth contours in the Cordillera del Viento area computed from a gravity inversion model (see text for details). Contours show an inflection at the site of the identified NW Tucuyo transfer zone describing a stair-like geometry through the Cordillera del Viento eastern emergent front. Another transfer zone is identified between the northern termination of the Cordillera del Viento and the Alto de Curileuvú High to the northeast.

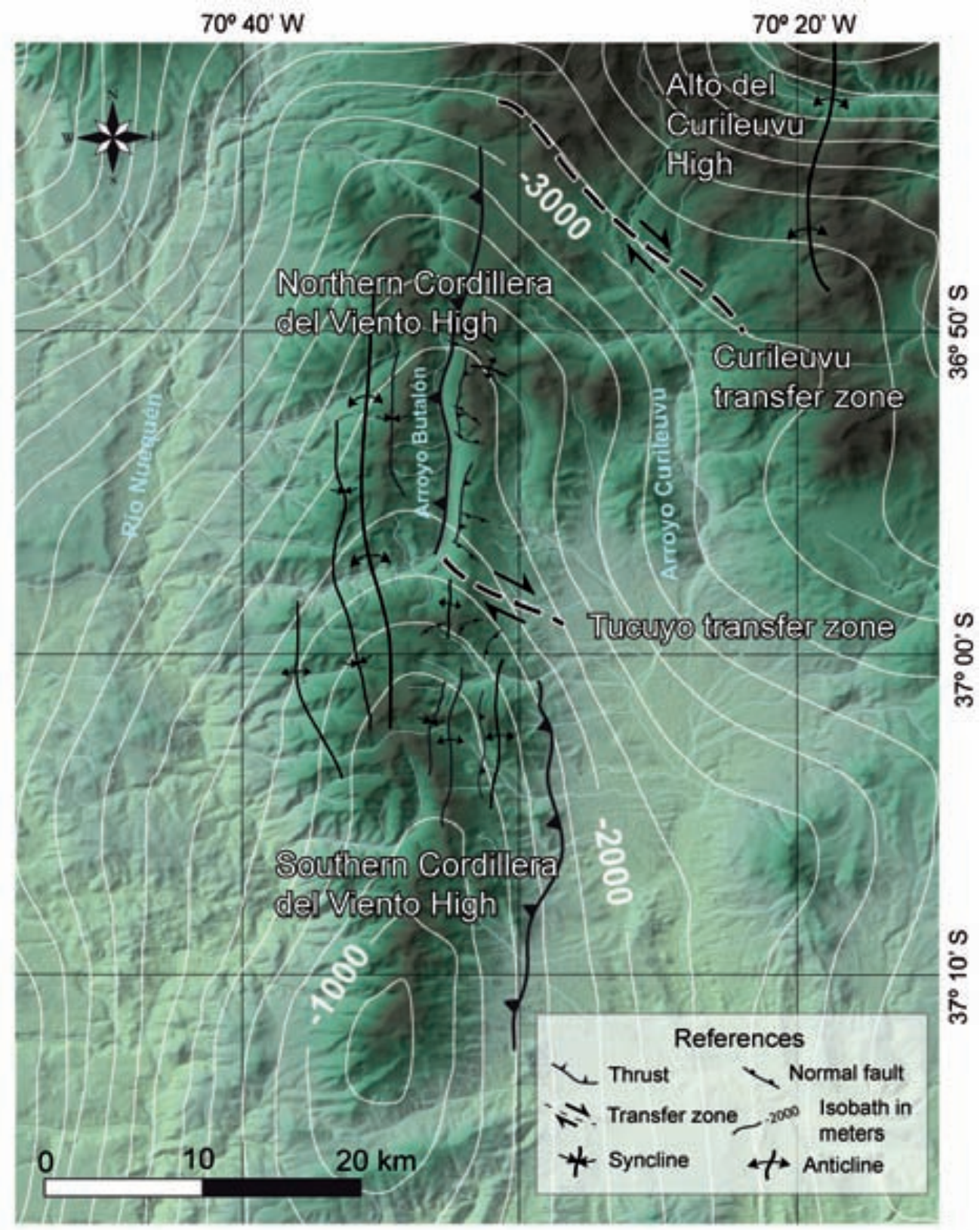




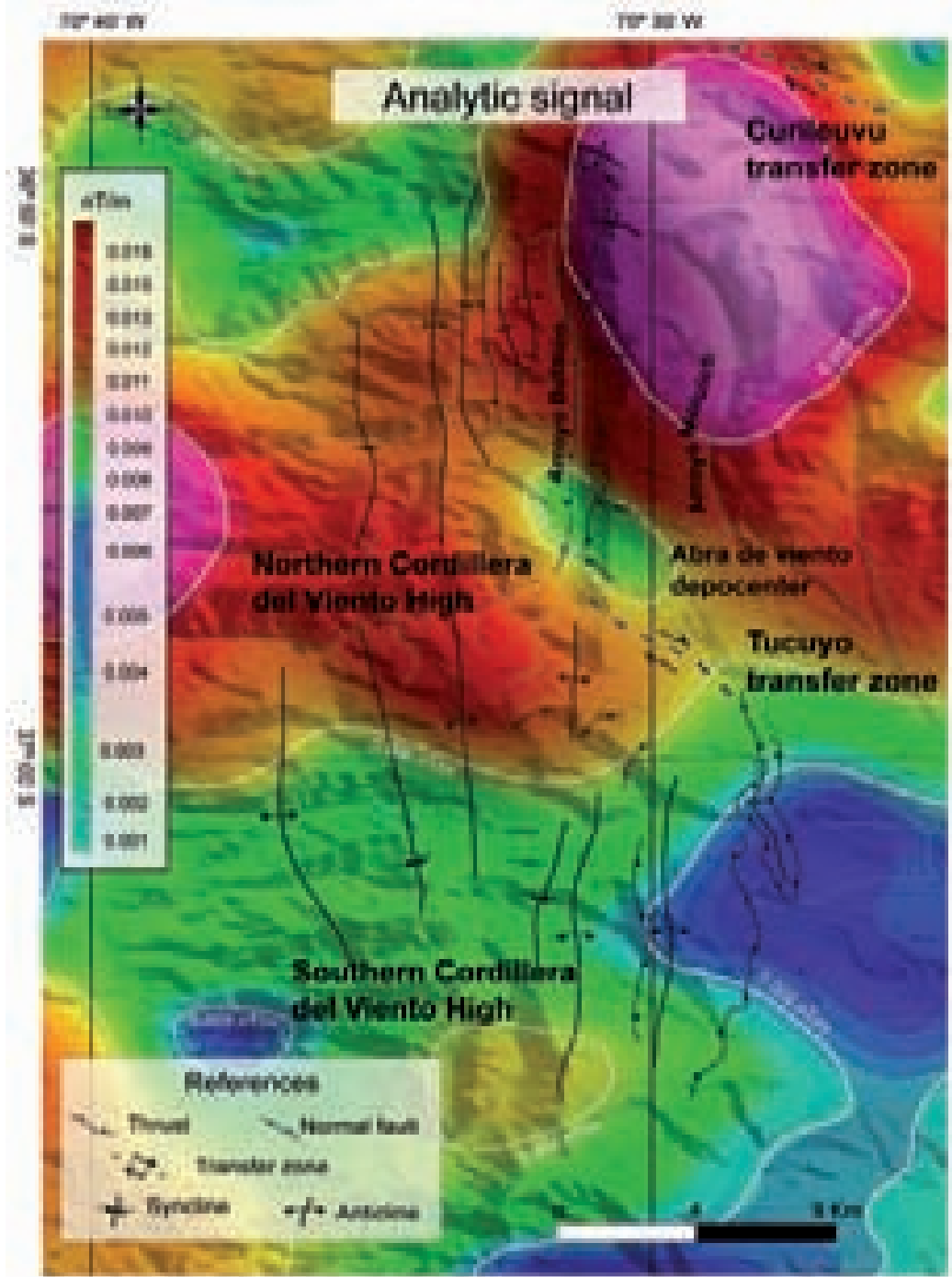

Fig. 14.- Analytic signal computed from vertical and horizontal gradients of the magnetic anomalies in the study area that enhances limits of bodies with anomalous magnetic susceptibility. Magnetic data are from a compilation of terrestrial and aeromagnetic measurements. Note that anomaly contours describe a pattern formed by two main structures, with W-NW and NE directions. Note that in most cases $\mathrm{N}$ - trending contractional structures cut that pattern indicating no evident control.

Fig 15.- 3D Block diagram constructed with TM draped on top of a DEM. Relationship between primary reverse faults that uplift the Cordillera del Viento and rift orientation determined from geological and geophysical data segmented by W-NW to NW and NE depocenters.

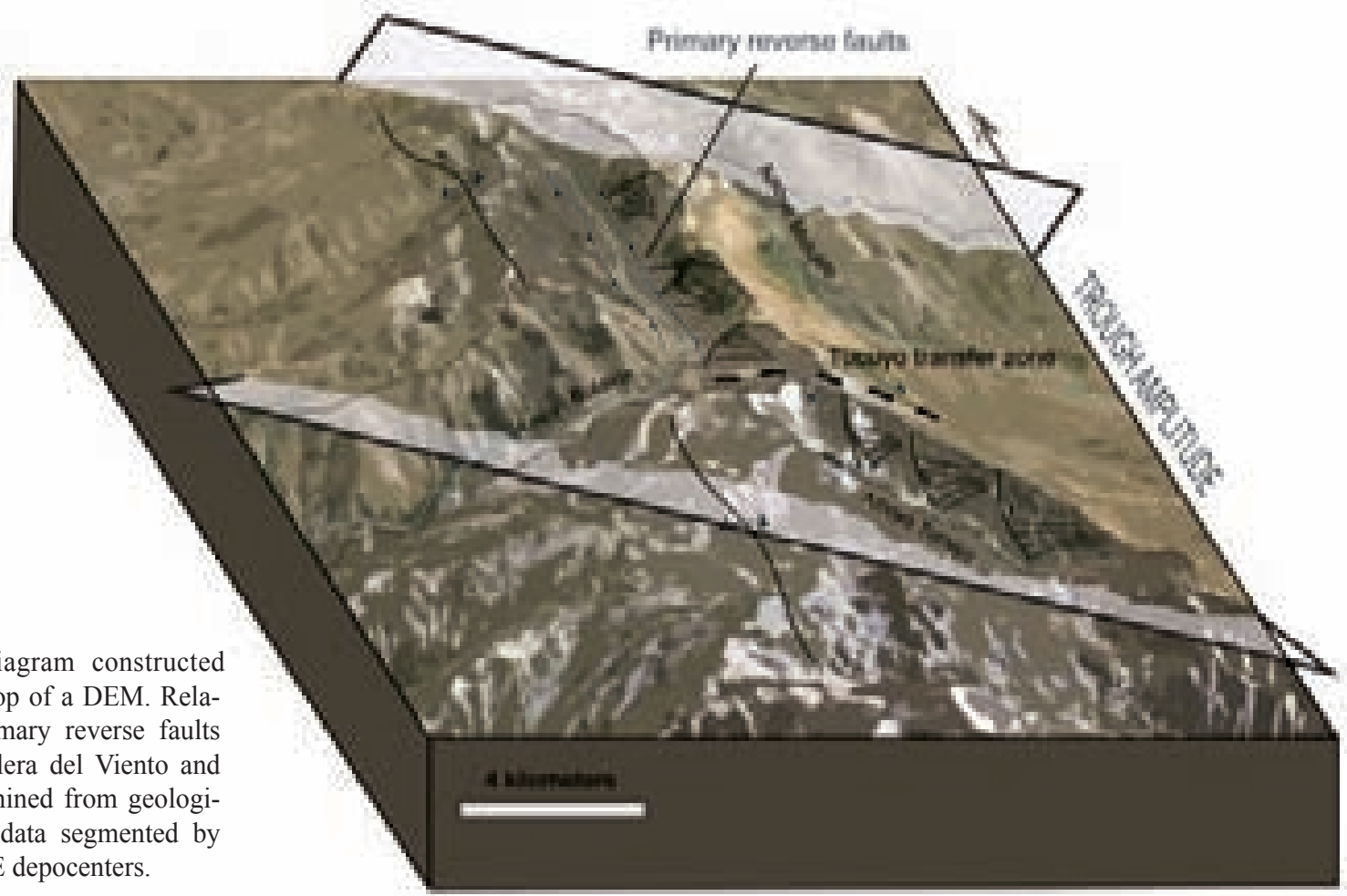


Based on the structures described in the field and their correlation with the geophysical data is highly probable that the $\mathrm{N}$-trending Andean contractional structures were not clearly related to reactivation of previous normal faults. These thrusts could be considered as primary faults without previous controls that cut through the Late Triassic rifting architecture. As field data demonstrate, previous normal structures are selectively reactivated as contractional and transfer faults. W-NW and NW normal faults seem to act as transfer contractional structures while NE normal faults would absorb frontal contractional deformation during rifting inversion. Main Noriented Andean structures locally exhumed synextensional geometries that were contained in depocenters, bypassing normal faults.

Then, rifting architecture would correspond to NW oriented troughs segmented by NE shorter normal faults (Fig. 15). Their inversion involves reactivation of NE structures decoupling and transferring shortening between a series of basement blocks, and new N-S thrusts without previous controls that locally exhume synrift geometries.

\section{Acknowledgments}

The authors want to acknowledge Dr. E. Llambías and G. Zamora Valcarce for their critical reviews that help to enhance the results of the study. This is the contribution R-97 of the Instituto de Estudios Andinos Don Pablo Groeber (UBACONICET).

\section{References}

Amos, A.J. (1972): Las cuencas carbónicas y pérmicas de Argentina. Simposio Internacional, Sistema Carbónico-Pérmico América do Sul. Río de Janeiro. Anales de la Academia Brasilera de Ciencias, 44: 2736.

Araneda, M., Avendaño, M.S. Merlo, C. (2000): Modelo gravimétrico de la Cuenca de Santiago, etapa III final. Resumen. Actas IX Congreso Geológico Chileno, Puerto Varas, 404-408.

Azcuy, C.L., Caminos, R. 1(987): Diastrofismo. In S. Archangelsky (ed.) El Sistema Carbonifero en la República Argentina. Academia Nacional de Ciencias, Córdoba. 239-251

Bechis, F., Giambiagi, L.B., García, V.H., Lanés, S., Cristallini, E.O., Tunik, M. (2010): Kinematic analysis of a transtensional fault system: The Atuel depocenter of the Neuquén basin, southern Central Andes, Argentina. Journal of Structural Geology 32: 886 - 899. doi: 10.1016/j.jsg.2010.03.009

Blakely, R. J. (1995): Potential theory in gravity and magnetic applications. Cambridge University Press. 441 p.

Burns, W.M., Jordan, T.E., Copeland, P.,Kelley, S.A. (2006): The case for extensional tectonics in the Oligocene-Miocene Southern Andes as recorded in the Cura Mallin basin $\left(36^{\circ}-38^{\circ}\right.$ S). In S.M. Kay and V.A. Ramos (eds.), Evolution of an Andean margin: A tectonic and magmatic view from the Andes to the Neuquén basin $\left(35^{\circ}-39^{\circ} \mathrm{S}\right.$ lat $)$. Geological Society of America Special Paper 407: 163-184. doi: 10.1130/2006.2407(08)

Charrier, R., Pinto, L., Rodríguez, M.P. (2007): Chapter 3: Tectonostratigraphic evolution of the Andean Orogen in Chile. In: T. Moreno and W. Gibbonds (Eds.). The Geology of Chile. Geological Society of
London: 21-114.

Cobbold, P., Rossello, E. (2003): Aptian to Recent compressional deformation in the foothills of the Neuquén basin Argentina. $\mathrm{Ma}$ rine and Petroleum Geology 20 (5): 429-443. doi:10.1016/S02648172(03)00077-1

Cristallini, E.O., Ramos, V.A. (2000): Thick-skinned and thin-skinned thrusting in the La Ramada fold and thrust belt: crustal evolution of the High Andes of San Juan, Argentina ( $\left.32^{\circ} \mathrm{SL}\right)$. Tectonophysics 317: 205-235. doi: 10.1016/S0040-1951(99)00276-0

Digregorio, J.H., Uliana, M.A. (1980): Cuenca Neuquina. In J.C.M. Turner (Ed.), Segundo Simposio de Geología Regional Argentina, Cordoba. Academia Nacional de Ciencias 2: 985-1032.

Farías, M., Charrier, R., Carretier, S., Martinod, J., Fock, A., Campbell, D., Cáceres, J., Comte, D. (2008): Late Miocene high and rapid surface uplift and its erosional response in the Andes of central Chile $\left(33^{\circ}-35^{\circ} \mathrm{S}\right)$. Tectonics 27. doi:10.1029/2006TC002046, 2008.

Folguera, A., Ramos, V.A., Zapata, T.R., Spagnuolo, M.G. (2007): Andean evolution at the Guañacos and Chos Malal fold and thrust belts $\left(36^{\circ} 30^{\prime}-37^{\circ} \mathrm{S}\right)$. Journal of Geodynamics. 44: 129-148. doi: 10.1016/j.jog.2007.02.003

Franzese, J.R., Spalletti, L.S. (2001): Late Triassic - early Jurassic continental extension in southwestern Gondwana: tectonic segmentation and pre-break-up rifting. Journal of South American Earth Sciences 14, 257 - 270. doi: 10.1016/S0895-9811(01)00029-3

Giacosa, R., Allard, J., Foix, N., Heredia, N. (2014): Stratigraphy, structure and geodynamic evolution of the Paleozoic rocks in the Cordillera del Viento ( $37^{\circ} \mathrm{S}$ latitude, Andes of Neuquén, Argentina). Journal of Iberian Geology 40 (2), 331-348. doi: 10.5209/rev_JIGE.2014.v40. n2.45301

Giambiagi, L.B., Bechis, F., García, V.H., Clark, A. (2008): Temporal and spatial relationships of thick - and thin - skinned deformaion in the Malergüe fold and thrust belt, Southern Central Andes. Tectonophysics 459 (1-4): 123-139. doi:10.1016/j.tecto.2007.11.069

Groeber, P. (1946): Observaciones geológicas a lo largo del meridiano $70^{\circ}$. 1. Hoja Chos Malal. Revista de la Sociedad Geológica Argentina 1(3): 177-208.

Hinze, W. J. (2003): Bouguer reduction density, why 2.67? Geophysics 68: 1559-1560. doi: 10.1190/1.1620629

Introcaso, B. (1998): Prony's method applied to anomalies' separation on an Andean Cordillera section. Geoacta 23: 41-50

JICA, Japan International Cooperation Agency, (1992): Report on the northern Neuquén geothermal development project. International cooperation Agency. Ente Provincial de Energía de la Provincia de Neuquén. Project. Final Report: 89 p.

Kane, M.F. (1962): A comprehensive system of terrain corrections using a digital computer. Geophysics 27: 455-462.

Kozlowski, E., Manceda, R., Ramos, V.A. (1993). Chapter 18: Estructura. In V.A. Ramos (Ed.), Geología y Recursos Naturales de Mendoza. XVII Congreso Geológico Argentino y II Congreso de Exploración de Hidrocarburos, Mendoza: 235-256.

Leanza, H. A., Llambías, E. J., Carbone, O. (2005): Unidades estratigráficas limitadas por discordancias en los depocentros de la Cordillera del Viento y la Sierra de Chacaico durante los inicios de la Cuenca neuquinca. Actas VI Congreso de exploración de hidrocarburos. Trabajos técnicos. Reservorios y desarrollo de reservas, Mar del Plata., (CD) $13 \mathrm{p}$

Leanza, H.A., Mazzani, A., Corfu, F., Llambías, E.J., Svensen, H., Planke, S., Galland, O. (2013): The Chachil Limestone (Pliensbachian earliest Toarcian) Neuquén Basin, Argentina: $\mathrm{U}-\mathrm{Pb}$ age calibration and its significance on the Early Jurassic evolution of the southwestern Gondwana. Journal of South American Science 42: 171 - 185. doi.org/10.1016/j.jsames.2012.07.012

Legarreta, L., Gulisano, C.A. (1989): Chapter 6.: Análisis estratigráfico 
secuencial de la cuenca neuquina (Triásico Superior-Terciario Inferior), Argentina. In G.A. Chebli and L.A. Spalleti (Eds.). Cuencas Sedimentarias Argentinas. Facultad de Ciencias Naturales, Universidad Nacional de Tucumán, Serie Correlación Geológica: 221-243.

Llambías, E.J. (1986): Intrusivos pérmicos del sur de la Cordillera del Viento, provincia del Neuquén. Revista de la Asociación Geológica Argentina 41(1-2): 22-32.

Llambías, E.J, Danderfer, J.C., Palacios, M., Brogioni, N. (1978): Las rocas igneas cenozoicas del Volcán Domuyo y áreas adyacentes, Provincia de Neuquén. Actas VII Congreso Geológico Argentino, Neuquén, 2: 569-584

Llambías, E.J., Leanza, H.A., Carbone, O. (2007): Evolución tectonomagmática durante el Pérmico al Jurásico temprano en la Cordillera del Viento $\left(37^{\circ} 05^{\prime} \mathrm{S}-37^{\circ} 15^{\prime} \mathrm{S}\right)$ : Nuevas evidencias geológicas y geoquímicas del inicio de la Cuenca neuquina. Revista de la Asociación Geológica Argentina 62 (2): 217 -235.

Manceda, R., Figueroa, D. (1995): Inversion of the Mesozoic Neuquen rift in the Malargtie fold and thrust belt, Mendoza, Argentina.. In A. J., Tankard, R. Suarez and H.J. Welsink (Eds), Petroleum basins of South America. Memoirs of the American Association of Petroleum Geologists 62: 369-382.

Nabighian, M.N. (1972): The analytic signal of two-dimensional bodies with polygonal cross section: its properties and use for automated anomaly interpretation. Geophysics 37: 507-517.

Orts, D.L., Folguera, A., Giménez, M., Ramos, V.A. (2011): Variable structural controls through time in the Southern Central Andes $\left(\sim 36^{\circ} \mathrm{S}\right)$. Andean Geology 39 (2): 220-241. doi: 10.5027/andgeoV39n2-a02

Pángaro, F., Martinez, R., Sattler, F., Bettini, F. (2011): Chapter 36: El Flanco Oriental. In H. A. Leanza, C. Arregui, O. Carbone, J.C. Danielli, J.M. Vallés. (Eds.), Relatorio del XVIII Congreso Geológico Argentino, Neuquén, 407-418.

Parker R.L. (1973): The rapid calculation of potential anomalies. Geophysical Journal of the Royal Astronomical Society 31 (4): 449-445.

Popowski, T., Connard, G., French, R. (2006): GMSYS-3D: 3D Gravity and Magnetic Modeling for Oasis Montaj. User Guide, Northwest Geophysical Associates, Corvallis, Oregon.

Ramos, V.A. (1998): Estructura del sector occidental de la Faja Plegada y Corrida del Agrio, Cuenca Neuquina, Argentina. Actas X Congreso Latinoamericano de Geología, Buenos Aires, 2: 105 - 110.

Ramos, V.A., Kay, S.M. (2006): Overview of the tectonic evolution of southern Central Andes of Mendoza and Neuquén $\left(35^{\circ}-39^{\circ} \mathrm{S}\right.$ lat). In S.M. Kay and V.A. Ramos (Eds.), Evolution of an Andean margin: A tectonic and magmatic view from the Andes to the Neuquén Ba$\sin \left(35^{\circ}-39^{\circ} \mathrm{S}\right.$ lat). Geological Society of America, Special Paper 407: 1-17. doi: 10.1130/2006.2407(01).

Ramos, V.A., Mosquera, A., Folguera, A., García Morabito, E. (2011): Chapter 29: Evolucíon tectónica de los Andes y del Engolfamiento Neuquino adyacente. In H. A. Leanza, C. Arregui, O. Carbone, J.C. Danielli, J.M. Vallés (Eds.), Relatorio del XVIII Congreso Geológico Argentino, Neuquén, 335-348.

Rodríguez Fernández, L.R., Heredia, N., Espina, R.G., Cegarra, M.I. (1997): In P. Busquets, F. Colombo, A. Pérez - Estaún, R. Rodríguez Fernández. (Eds.). Estratigrafia y estructura de los Andes Centrales Argentinos entre los $30^{\circ}$ y $31^{\circ}$ de Latitud Sur. Geología de los Andes Centrales Argentino - Chilenos. Acta Geológica Hispánica 32 (1-2): $51-75$

Roest, W.R., Verhoef, J., Pilkington, M. (1992): Magnetic interpretation using the 3-D analytic signal. Geophysiscs 57 (1): 116-125.

Rolleri, E.O., Criado Roque, P. (1970): Geología de la provincia de Mendoza. Cuartas Jornadas Geológicas Argentinas, 2: 1-60.

Sato, A.M., Llambías, E.J., Basei, M.A.S., Leanza, H.A. (2008): The Permian Choiyoi cycle in Cordillera del Viento (Principal Cordill- era, Argentina): over $25 \mathrm{Ma}$ of magmatic activity. Abstract. VI South American Symposium of Isotope Geology, San Carlos de Bariloche, p.102.

Silvestro, J., Atencio, M. (2009): La cuenca cenozoica del Río Grande y Palauco: edad, evolución y control estructural, Faja plegada de Malargüe $\left(36^{\circ} \mathrm{S}\right)$. Revista de la Asociación Geológica Argentina 65 (1): 154-169.

Spalletti, L.A. (1997): In P. Busquets, F. Colombo, A. Pérez - Estaún, R. Rodríguez Fernández. (Eds.). Cuencas Triásicas del oeste Argentino: Origen y Evolución. Geología de los Andes Centrales Argentino - Chilenos. Acta Geológica Hispánica 32 (1-2): 29 - 50

Suárez, M., De la Cruz, R. (1997): Volcanismo pliniano del Lías durante los inicios de la cuenca de Neuquén, Cordillera del Viento, Neuquén, Argentina. Actas VIII Congreso Geológico Chileno, Antofagasta, 1: 266-270.

Suárez, M., de la Cruz, R., Fanning, M., Etchart, H. (2008): Carboniferous, Permian and Toarcian magmatism in Cordillera del Viento, Neuquén, Argentina: first U-Pb shrimp dates and tectonic implications. $17^{\circ}$ Congreso Geológico Argentino, S.S. de Jujuy, Argentina. Actas II: 906-907.

Tunik, M., Folguera, A., Naipauer, M., Pimente, M., Ramos, V.A. (2010): Early uplift and orogenic deformation in the neuquén basin: constraints on the Andean uplift from $\mathrm{U}-\mathrm{Pb}$ and $\mathrm{Hf}$ isotopic data of detrital zircons. Tectonophysics 489, 258 - 273. doi.org/10.1016/j. tecto.2010.04.017.

Uliana, M., Biddle, K., Cerdán, J. (1989): Extensional Tectonics and Stratigraphy of the North Atlantic Margin. In A. J., Tankard, R. Suarez and H.J. Welsink (Eds.), Petroleum basins of South America. Memoirs of the American Association of Petroleum Geologists 46: 599-613

Vergani, G.D., Tankard, A.J., Belotti, H.J., Welsink, H.J. (1995): Tectonic evolution and paleogeography of the Neuquén basin, Argentina. In A. J., Tankard, R. Suarez and H.J. Welsink (Eds.), Petroleum basins of South America. Memoirs of the American Association of Petroleum Geologists 62: 383-402.

Yagupsky, D.L., Critallini, E.O., Fantín, J., Zamora Valcarce, G., Bottesi, G., Varadè, R. (2008): Oblique half - graben inversion of the Mosozoic Neuquèn Rift in the Malargúe Fold and Thrust Belt, Mendoza, Argentina: New insights from analogue models. Journal of Structural Geology 30: 839 - 853. doi:10.1016/j.jsg.2008.03.007

Zamora Valcarce, G., Zapata, T.R. (2005): Estilo estructural del frente de la faja plegada neuquina a los $37^{\circ} \mathrm{S}$. Actas VI Congreso de exploración y desarrollo de Hidrocarburos. Mar del Plata, (CD) 16 p.

Zamora Valcarce, G., Zapata, T.R., Del Pino, D., Ansa, A. (2006): Structural evolution and magmatic characteristics of the Agrio foldand-thrust belt. In S.M. Kay and V.A. Ramos (eds.), Evolution of an Andean margin: A tectonic and magmatic view from the Andes to the Neuquén basin $\left(35^{\circ}-39^{\circ} \mathrm{S}\right.$ lat). Special Paper of the Geological Society of America 407: 125-145. doi:10.1016/j.jsg.2008.03.007.

Zamora Valcarce, G., Zapata, T.R., Ramos, V.A., Rodríguez, F., Bernardo, L.M. (2009): Evolución Tectónica del frente Andino en Neuquén. Revista de la Asociación Geológica Argentina 65 (1): 192 - 203.

Zanettini, J.C., Santamaría, G.R., Leanza, H.A. (2001): Hoja de la Carta Geológica de la República Argentina E. 1:250.000 num. 3772-II (Las Ovejas) Provincia del Neuquén. Instituto de Geología y Recursos Minerales, Servicio Geológico Minero Argentino. Secretaría de Minería, Argentina, Boletín 263: 61p.

Zapata, T.R., Brissòn, I., Dzelalija, F. (1999): The role of basement in the Andean fold and thrust belt of the Neuquén Basin. In K. McClay (Ed.), Thrust tectonics. Conference. VI, London, 122-124.

Zapata, T.R., Córsico, S., Dzelalija, F., Zamora Valcarce, G. (2002): La faja plegada y corrida del Agrio: Análisis estructural y su relación con los estratos terciarios de la cuenaca neuquina, Argentina. Actas 
$V$ Congreso de exploración y desarrollo de Hidrocarburos, Mar del Plata, (CD).

Zappettini, E., Méndez, V., Zanettini, J.C. (1987): Metasedimentitas mesopaleozoicas en el noroeste de la Provincia del Neuquén. Revista de la Asociación Geológica Argentina 42 (1-2): 206-207.

Zappettini, E.O., Chernicof, C.J., Santos, J.O.S., Dalponte, M., Belousova, E., McNaughton, N. (2012): Retrowedge-related Carboniferous units and coeval magmatism in the northwestern Neuquén province, Argentina. International Journal of Earth Science 101: 2083-2104. doi:10.1007/s00531-012-0774-3.

Zöller, W., Amos A.J. (1973): Hoja de la Carta Geológica de la República Argentina E. 1:100.000 num 32b (Chos Malal) provincia del Neuquén. Servicio Nacional Geológico Minero, Boletín 143: 91p. 